\title{
National Geographic Society Kids Network: Report on 1994 Teacher Participants
}

March 1995

Prepared by:

Program Evaluation and Assessment Group Science/Engineering Education Division

Oak Ridge Institute for Science and Education 


\title{
DOE/OR/00033--T651
}

\section{National Geographic Society Kids Network: Report on 1994 Teacher Participants}

\author{
Prepared by: \\ Program Evaluation and Assessment Group \\ Science/Engineering Education Division \\ Oak Ridge Institute for Science and Education \\ Oak Ridge, Tennessee 37831-0117
}

\section{DISCLAIMER}

\begin{abstract}
This report was prepared as an account of work sponsored by an agency of the United States Government. Neither the United States Government nor any agency thereof, nor any of their employees, makes any warranty, express or implied, or assumes any legal liability or responsibility for the accuracy, completeness, or usefulness of any information, apparatus, product, or process disclosed, or represents that its use would not infringe privately owned rights. Reference herein to any specific commercial product, process, or service by trade name, trademark, manufacturer, or otherwise does not necessarily constitute or imply its endorsement, recommendation, or favoring by the United States Government or any agency thereof. The views and opinions of authors expressed herein do not necessarily state or reflect those of the United States Government or any agency thereof.
\end{abstract}

March 1995

This report is based on work performed under Contract No. DE-AC05-76OR00033 between the U.S. Department of Energy and Oak Ridge Associated Universities.

All opinions expressed in this paper are the authors' and do not necessarily reflect policies and views of the U.S. Department of Energy or the Oak Ridge Institute for Science and Education. 


\section{DISCLAIMER}

Portions of this document may be illegible in electronic image products. Images are produced from the best available original document. 


\section{Table of Contents}

Report Highlights ................................................................................................... iii

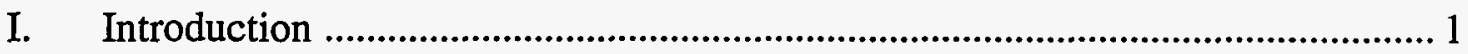

II. Characteristics of 1994 NGS Kids Network Participants ....................................... 2

III. Exit Data for 1994 NGS Kids Network Participants ............................................ 9

IV. Comparison of Responses Before and After 1994 NGS Kids Network Program ................................................................................................ 13

V. Summary of Open-Ended Comments .................................................................. 14

Appendix A. 1994 Entry Questionnaire .................................................................... 16

Appendix B. 1994 Exit Questionnaire ........................................................................ 24

Appendix C. 1994 Responses to Open-Ended Questions on Exit Form...................... 28

Appendix D. 1994 Responses to Participant Evaluation of Daily Activity .................. 45 


\section{National Geographic Society Kids Network: Report on 1994 Teacher Participants}

\section{Report Highlights}

In 1994, National Geographic Society Kids Network, a computer/telecommunications-based science curriculum, was presented to elementary and middle school teachers through summer programs sponsored by the National Geographic Society (NGS) and the U.S. Department of Energy (DOE). This report assesses the impact of the NGS Kids Network program on the participating teachers. Some of the major findings are summarized below.

- A total of 99 elementary and middle school teachers participated in the NGS Kids Network program at $5 \mathrm{DOE}$ facilities. Entry and exit data were collected by the facilities to determine the impact of the program.

- In the group of participants, females outnumbered males ( 84 percent versus 16 percent), 22 percent represented minorities, half held advanced degrees, and the average number of years of full-time teaching was 15 .

- When asked about the effects of their program participation, almost all of the participants said they had a better understanding about how computers are used as tools to assist scientists ( 99 percent) and that they will be able to use computers to teach their students (99 percent).

- All of the participants indicated they could see ways to integrate the NGS Kids Network programs into their curriculum, and 99 percent would recommend the workshop to other teachers.

- Participants rated their knowledge, understanding, and interest relating to research and science/mathematics/technology more positively after the NGS Kids Network program than before.

- Logistical and administrative aspects of the program were also highly rated by participants, with the highest marks going to the knowledgeable, professional and enthusiastic presenter(s) and the assistance provided by program administrative staff. 


\section{Introduction}

Since 1992, the U.S. Department of Energy (DOE) and the National Geographic Society (NGS) have joined resources to sponsor a program of summer institutes to introduce school teachers of grades 3 through 7 to the NGS Kids Network, with priority given to school districts that recommend two or more teachers. The NGS Kids Network is an innovative computer and telecommunications-based science and geography curriculum that offers hands-on experience in scientific methods; builds skills in communication, problem solving, graphing, map reading and mathematics; expands cultural and social awareness; teaches the many ways computer technologies are used in the real world; and through telecommunications, enables students to share information on an international basis.

In 1994, the one-week summer institutes were held at 5 DOE facilities, with NGS providing the trainer to conduct the sessions with teachers. During the sessions, the teachers learned how to use the NGS Kids Network program and how to integrate the materials into their curriculum, became familiar with the computer technology, participated in hands-on science and math activities related to the NGS Kids Network, toured research facilities carrying out related research, and enhanced their teaching skills.

The general objective of the program is to bring about reform in the area of science and mathematics education. In specific, the NGS Kids Network program assists teachers in understanding the process of doing science; understanding the role of computers and telecommunications in the study of science, math, and engineering; and utilizing computers and telecommunications appropriately in the classroom. The program enables teachers to integrate science, mathematics, and technology with other subjects with the ultimate goal of encouraging students of all abilities to pursue careers in science, mathematics, and engineering.

\section{Assessment Methodology}

Based on a plan developed by ORISE, a summer assessment staff member was responsible for the primary assessment of the NGS Kids Network program. The staff member was a teacher participating as a summer Teacher Research Associate, a program sponsored by the U.S. Department of Energy. He was assisted in this effort by the summer assessment coordinator, a teacher who had previous experience with the assessment of ORISE's precollege programs, and by ORISE evaluation and program staff.

In addition to the specific assessment activities associated with NGS Kids Network, the assessment staff member was responsible for developing a procedures manual to brief subsequent staff in assessment of future programs. This endeavor was one component of a larger capacity-building effort within the ORISE program with broad responsibility for precollege educational programs'.

'Cain, Linda C., \& Clark, Sheldon B. (1994, September) - Evaluation of K-12 Programs at ORISE: A Case Study in Capacity-Building, Science/Engineering Education Division, Oak Ridge Institute for Science and Education, Oak Ridge, TN. 
Data collection for the NGS Kids Network was accomplished primarily through three questionnaires and through interviews conducted by the assessment staff member. An entry questionnaire was utilized to collect background information, to assess teacher attitudes upon their entry into the program, and to collect some background information. Another form (Participant Evaluation of Daily Activity) was used to record reactions to and information gained from daily sessions, and the application back into the classroom. The exit questionnaire repeated some of the entry questions in an attempt to document changes in attitudes before and after the NGS Kids Network experience. In addition, the exit questionnaire asked teachers to assess the program content and also the administrative and logistical aspects of program operations. Responses to open-ended questions on the exit form are included in Appendix $\mathrm{C}$ of this report. Included in Appendix D are the responses to the Participant Evaluation of Daily Activity form.

The data collected, both quantitative and qualitative, are summarized in this report. In addition, comparisons between entry and exit data are used to document changes in attitudes.

\section{Characteristics of 1994 NGS Kids Network Participants}

This section of the report summarizes entry information on participants in the 1994 NGS Kids Network program, which was collected by the DOE facilities at the beginning of the one-week sessions. A total of 99 teachers from 5 sites completed the forms that requested entry data. The sites included Ames Laboratory, Los Alamos National Laboratory, Oak Ridge Institute for Science and Education, Princeton Plasma Physics Laboratory, and Sandia National Laboratories. The Oak Ridge Institute for Science and Education coordinated activities at all 5 locations.

Female teacher-participants outnumbered male teachers ( 84 percent and 16 percent, respectively) in the NGS Kids Network program, which is not surprising since the focus of the program is on elementary and middle school teachers. Of those participants reporting race/ethnicity, 22 percent represented minorities.

\section{Race/Ethnicity of 1994 NGS Kids Network Participants}

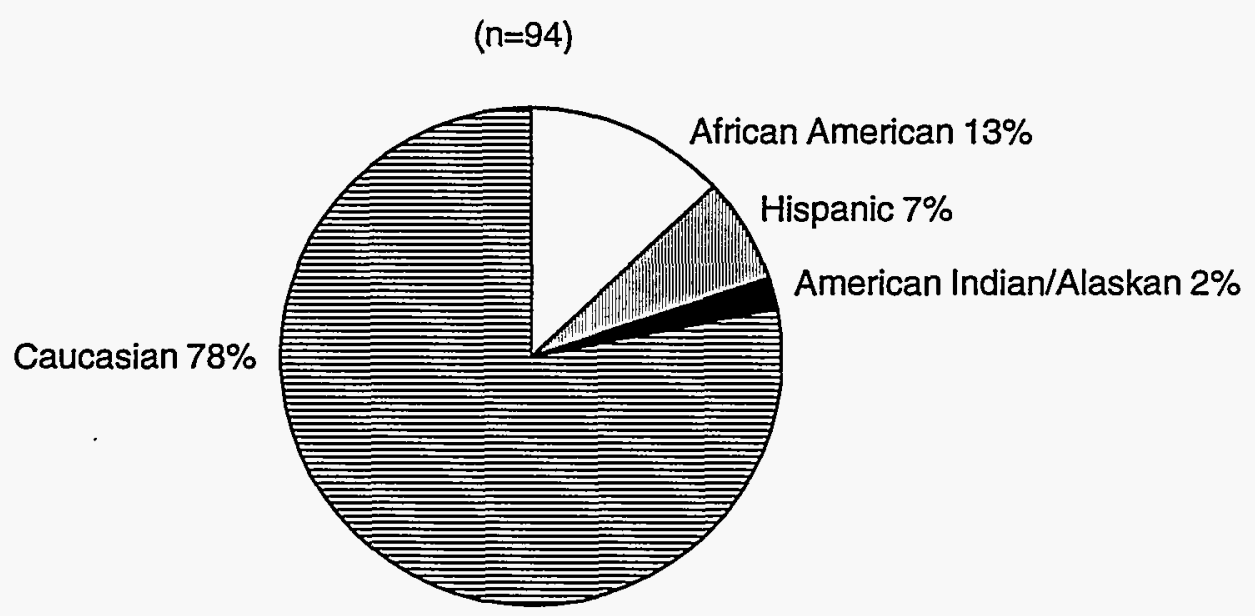




\section{Educational Data}

One-half of the teacher-participants reported their highest degree attained to be a master's degree or above. For those participants reporting credit hours earned beyond the highest degree, the number averaged 30 semester hours ( 79 participants reporting) and 27 quarter hours

(5 participants reporting). About 17 percent of all the participants indicated they were currently working toward an advanced degree. The participants were also asked to indicate the major field of study of their bachelor's degree; over two-thirds indicated a degree in elementary education.

Highest Degree Earned by 1994 NGS Kids Network Participants

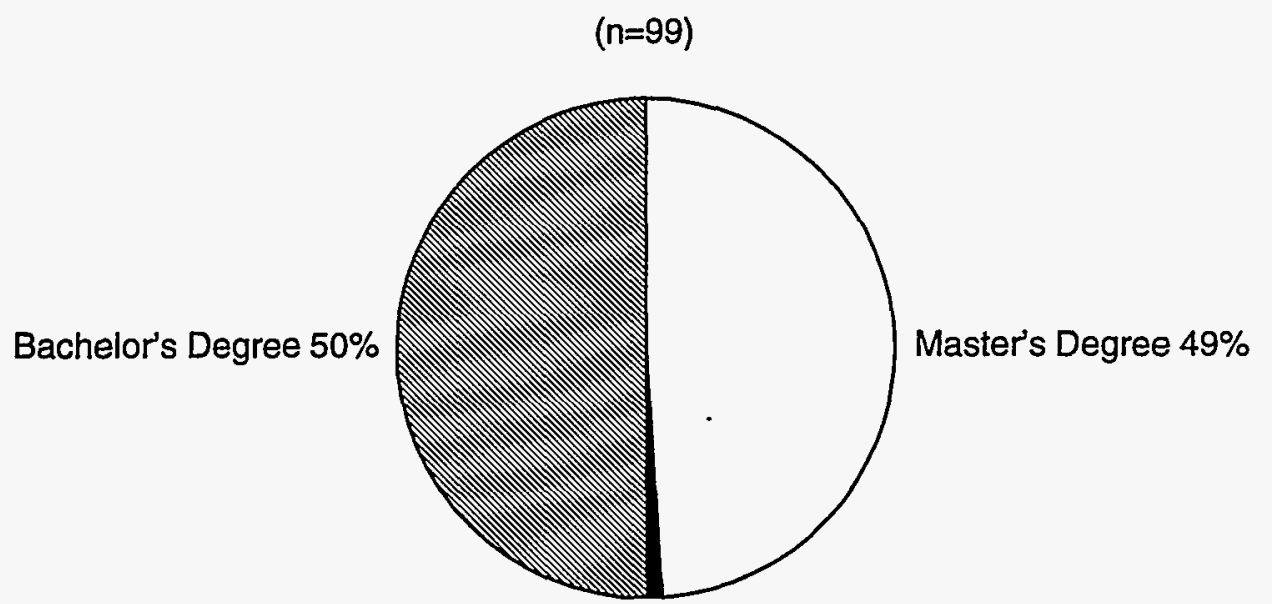

Ed. Specialist Degree 1\%

Major Field of Bachelor's Degree for 1994 NGS Kids Network Participants

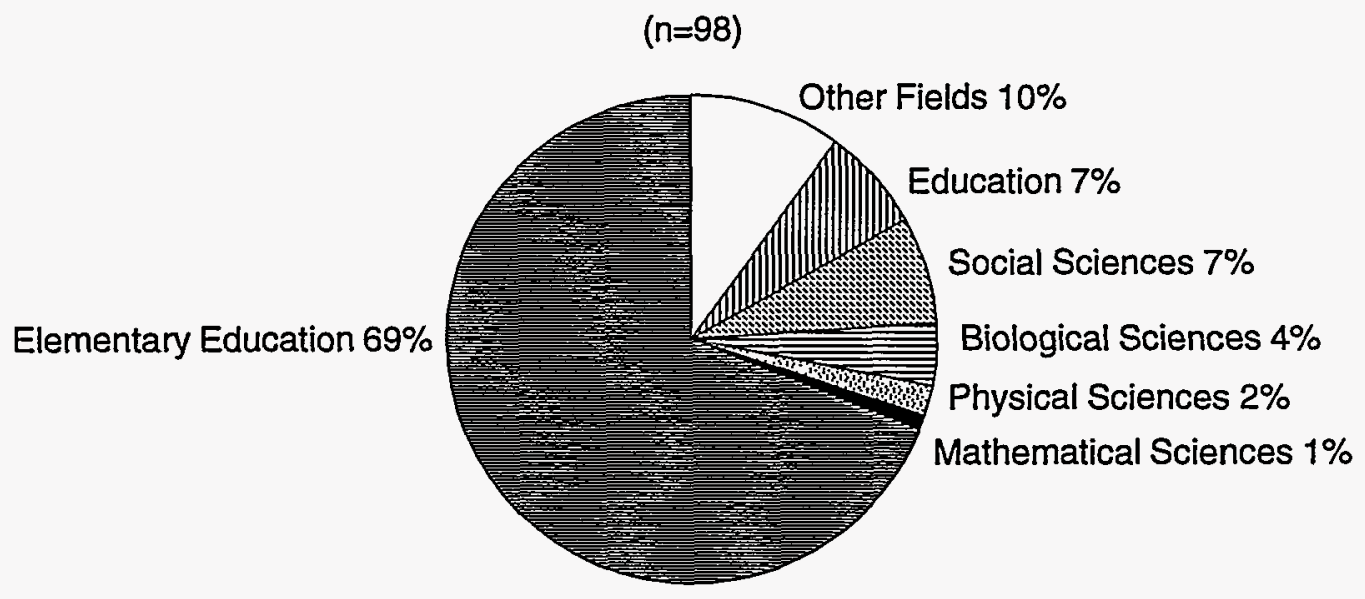




\section{Teaching Activities and Techniques}

Teachers were asked to indicate all levels at which they had taught; over three-fourths of the teacher-participants indicated elementary school, with 32 percent indicating they had taught middle school. In addition, 3 percent of the group indicated they had taught high school, with 6 percent reporting other assignments such as preschool, college, or adult GED classes. As a group, the teachers reported an average of 15 years of full-time teaching, with 31 teachers reporting an average of 3 years of part-time teaching experience. Almost 40 percent reported they had been responsible for conducting in-service or workshop activities, with topics including computers, science, mathematics, and assessment. The number of in-service or workshop activities ranged from 1 to 10 with a mean of 3 (39 participants reporting). In addition, 21 percent reported they had made presentations to professional groups during the past year. The groups they spoke to included principals and teachers, parents, county commissioners, and even teachers from Russia. The number of presentations ranged from 1 to 5 with a mean of 2 (19 participants reporting).

Since the NGS Kids Network program focuses on elementary and middle school teachers, most all teachers reported their current assignments to be in grades 3 through 7 . Teachers were also asked to supply information on the demographic composition of their schools. On average, the NGS Kids Network participants indicated they work at schools in which the community is 48 percent urban, 16 percent suburban, and 36 percent rural, with an average minority enrollment of 49 percent. The majority of the teacher-participants reported they were teaching science and mathematics, with three-fourths teaching technology. Of those teaching these subjects, 89 to 95 percent of the teachers indicated these subjects were integrated with other topics. Science classes taught were mainly grade-level specific, but also included, for example, research methodology, physical science, and environmental units. In addition to regular classroom math, some teachers taught hands-on math, advanced classes, basic skills, or general math. Technology classes included keyboarding, word processing, graphics, database and spreadsheet applications, and computer-aided instruction, in addition to specific topics integrated with other subjects.

Teaching Activities of 1994 NGS Kids Network Participants

\begin{tabular}{lcc} 
& \multicolumn{2}{c}{ Yes } \\
\cline { 2 - 3 } & Number & Percent \\
\hline $\begin{array}{l}\text { At your school, are there subject matter } \\
\text { departments (e.g., math departments, science } \\
\text { departments)? }\end{array}$ & 30 & $31 \%$ \\
$\begin{array}{l}\text { Was science integrated with other topics in your } \\
\text { teaching? }\end{array}$ & 87 & 95 \\
$\begin{array}{l}\text { Was mathematics integrated with other topics in } \\
\text { your teaching? }\end{array}$ & 84 & 94 \\
$\begin{array}{l}\text { Was technology integrated with other topics in } \\
\text { your teaching? }\end{array}$ & 76 & 89
\end{tabular}

Note: n's for these items ranged from 85 to 96 responses. 
Teacher-participants also provided information about the use of computers in their classrooms and the types of problems they had experienced. Note in the table that follows that drill and practice, games, and word processing were the choices for computer use of the largest percentages of teachers. Types of teacher use included databases, spreadsheets, telecommunications, and graphics. Student uses included word processing, telecommunications, and computer labs. The most frequently cited problems were the lack of equipment and software for student and teacher use.

The number of students in the teachers' classes ranged from 11 to 650 . (The wide variation in the numbers reported was possibly due to the fact that some teachers were specialists in a middle school where they taught a different set (5-6 periods) of students each semester.) On average, a large proportion of these students completed science fair projects or other independent research projects. The amount of class time devoted to labs in science, technology, and math classes averaged 32 percent (mean), and the amount of time devoted to demonstrations averaged 20 percent (mean).

\section{Use of Computers by 1994 NGS Kids Network Participants}

Percent

No use of computers

Teacher use:

Class management (grades, scheduling, etc.)

Word processing

Other

Student use:

Drill and practice

Networking (communication)

Games

Interactive video

Individualized lesson plans

Special projects

27

Other

Types of problems with computers:

No problems

Lack of equipment/software for teacher use

Lack of equipment/software for student use

Lack of technical support

Lack of teacher training for use of computers

Other

Note: Teachers checked all that applied, thus percentages do not sum to 100 percent.

$n=99$ responses. 


\section{Science/Mathematics/Technology Activities \\ of 1994 NGS Kids Network Participants}

\begin{tabular}{lccc} 
& Range & Mean & Median \\
\hline $\begin{array}{l}\text { Percentage of time spent on planning and } \\
\text { classroom management that involves computer } \\
\text { use }\end{array}$ & $2 \%-95 \%$ & $23 \%$ & $15 \%$ \\
$\begin{array}{l}\text { Percentage of student learning time that involves } \\
\text { computer use }\end{array}$ & $2 \%-100 \%$ & $15 \%$ & $10 \%$ \\
$\begin{array}{l}\text { Number of total students enrolled in science/ } \\
\text { mathematics/technology classes }\end{array}$ & $11-650$ & 67 & 28 \\
$\begin{array}{l}\text { Number of students completing projects for } \\
\text { science fairs }\end{array}$ & $1-375$ & 47 & 20 \\
$\begin{array}{l}\text { Number of students completing independent } \\
\text { research projects (other than projects for } \\
\text { science fairs) }\end{array}$ & $1-375$ & 48 \\
$\begin{array}{l}\text { Percentage of time devoted to student laboratory } \\
\text { (including activities that are conducted in the } \\
\text { regular classroom) in science/mathematics/ } \\
\text { technology classes }\end{array}$ & $2 \%-95 \%$ & $32 \%$ \\
$\begin{array}{l}\text { Percentage of time devoted to demonstration } \\
\text { experiments in science/mathematics/technology } \\
\text { classes }\end{array}$ & $1 \%-95 \%$ & $20 \%$ & $24 \%$ \\
\end{tabular}


Teaching techniques of NGS Kids Network participants are summarized in the table that follows, according to the frequency of use. Note that the more frequently used techniques included using writing as a tool, teamwork, and the integration of math, science, and technology in teaching.

\section{Teaching Techniques of 1994 NGS Kids Network Participants}

\begin{tabular}{|c|c|c|c|c|c|}
\hline \multirow[b]{2}{*}{ How often teachers use the following techniques: } & \multicolumn{5}{|c|}{ Percentage Distribution } \\
\hline & $\begin{array}{l}\text { Less than } \\
\text { Once a } \\
\text { Month }\end{array}$ & $\begin{array}{l}\text { At Least } \\
\text { Once a } \\
\text { Month } \\
\end{array}$ & $\begin{array}{l}\text { At Least } \\
\text { Once a } \\
\text { Week }\end{array}$ & $\begin{array}{c}\text { Just } \\
\text { About } \\
\text { Daily } \\
\end{array}$ & $\begin{array}{c}\text { Not } \\
\text { Applicable } \\
\end{array}$ \\
\hline Assign projects based on "real world problems" & $18 \%$ & $32 \%$ & $27 \%$ & $14 \%$ & $9 \%$ \\
\hline Assign teams to work on assignments & 5 & 12 & 43 & 36 & 4 \\
\hline Use writing as a tool for student learning in classroom & 2 & 7 & 23 & 62 & 6 \\
\hline Integrate math, science, and technology in teaching & 3 & 13 & 33 & 46 & 5 \\
\hline Assign oral reports or presentations to students & 22 & 45 & 16 & 8 & 9 \\
\hline $\begin{array}{l}\text { Provide students with hands-on laboratory } \\
\text { experiences }\end{array}$ & 9 & 21 & 42 & 24 & 4 \\
\hline $\begin{array}{l}\text { Counsel students on possible careers in math, } \\
\text { science, or technology }\end{array}$ & 26 & 27 & 17 & 4 & 26 \\
\hline Arrange field trips for students & 62 & 20 & 1 & 2 & 15 \\
\hline Bring guest speakers into the classroom & 61 & 20 & 4 & 0 & 15 \\
\hline Conduct scientific demonstrations for students & 11 & 41 & 29 & 4 & 15 \\
\hline Use team teaching or other collaborative efforts & 12 & 16 & 31 & 26 & 15 \\
\hline
\end{tabular}

Note: Most teachers responded to these items; n's for each item varied slightly, ranging from 93 to 99 . 


\section{General Attitudes Relating to Science, Math, and Technology}

At the beginning of the 1994 NGS Kids Network program, participants were asked to rate their knowledge, understanding, interest, and awareness related to science, math, and technology and their confidence related to teaching in these areas. Some of the items are asked again at the end of the program in order to make comparisons and note any gains. The entry/exit comparisons are included in Section IV of the report.

A summary of items relating to teachers' confidence is included in the following table. When a longer-term follow-up activity is used in the assessment of this program, then these items may be repeated to document any long-term gains associated with the program. In general, teachers appeared less confident in making presentations at in-service meetings and interacting with peers on scientific matters than in teaching or activities with students.

\section{General Attitudes of 1994 NGS Kids Network Participants Relating to Science, Math, and Technology}

\begin{tabular}{lccccccccc} 
& & \multicolumn{7}{c}{ Percentage Distribution } \\
\cline { 2 - 9 } $\begin{array}{l}\text { How teachers rate the following } \\
\text { (with 1=Low to 7=High): }\end{array}$ & $\begin{array}{l}\text { Mean } \\
\text { Rating }\end{array}$ & 1 1=Low & 2 & 3 & 4 & 5 & 6 & $7=$ High \\
\hline $\begin{array}{l}\text { My confidence in teaching my science/ } \\
\text { mathematics/technology classes }\end{array}$ & 5.1 & $0 \%$ & $6 \%$ & $8 \%$ & $18 \%$ & $21 \%$ & $27 \%$ & $20 \%$ \\
$\begin{array}{l}\text { My confidence in discussing science/ } \\
\text { mathematics/technology applications } \\
\text { with my students }\end{array}$ & 5.0 & 1 & 10 & 6 & 16 & 23 & 25 & 19 \\
$\begin{array}{l}\text { My confidence in supervising science } \\
\text { projects of my students }\end{array}$ & 5.3 & 1 & 7 & 8 & 11 & 21 & 22 & 30 \\
$\begin{array}{l}\text { My confidence in making presentations } \\
\text { at in-service meetings }\end{array}$ & 4.4 & 14 & 5 & 17 & 9 & 20 & 14 & 21 \\
$\begin{array}{l}\text { My confidence in interacting with peers } \\
\text { on scientific matters }\end{array}$ & 4.7 & 8 & 3 & 12 & 14 & 29 & 16 & 18
\end{tabular}

Note: Most teachers responded to these items with n's ranging from 96 to 99. 


\section{Exit Data for 1994 NGS Kids Network Participants}

At the end of the week-long NGS Kids Network program, the laboratories administered an exit questionnaire. The data summarized in this section of the report reflect participants' perceptions about the program and its effect on them; 94 participants provided exit data (although not all responded to every item). Because the workshop was only one week, the effects noted here cannot necessarily be interpreted as long-term ones; a follow-up survey administered at a later date will determine if the effects of the workshop were sustained over time.

The participants were asked to rate their overall satisfaction with the NGS Kids Network program on a scale of 1 to 10 , with 1 representing very dissatisfied and 10 representing very satisfied. The results were quite positive. Over 90 percent rated the workshop an 8,9 , or 10; the mean response was 9.0 .

\section{Overall Satisfaction Rating for Program by 1994 NGS Kids Network Participants}

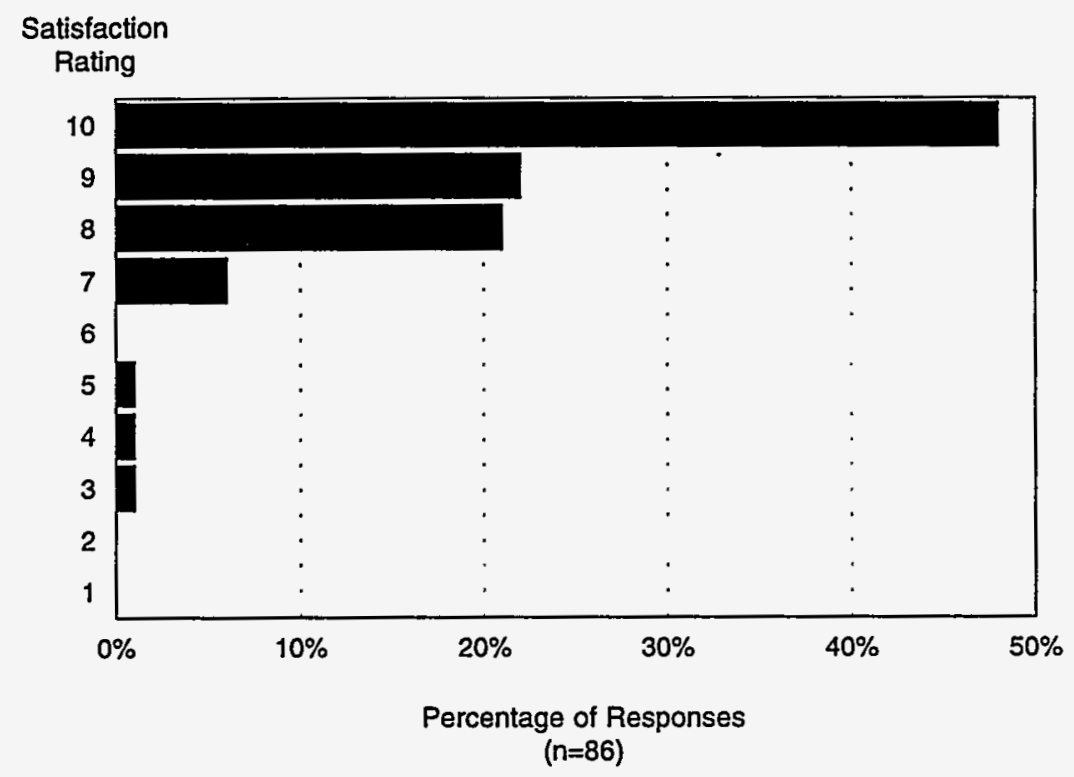




\section{Assessment of Program}

The teacher-participants provided information about the ways in which participating in the program had affected them. Most of the responses were very positive; greater than 96 percent responded "yes" to 8 of the 10 items. Almost all of the participants said they had a better understanding of how computers are used as tools ( 99 percent), and that they will be able to use computers to teach NGS Kids Network to their students (99 percent). Furthermore, 100 percent indicated they could see ways to integrate the NGS Kids Network program(s) into their curriculum, and 99 percent of the respondents would recommend the workshop to others. The workshop was relevant to the teacher's needs and lived up to their expectations ( 99 and 96 percent, respectively). In addition, the open-ended comments summarized later in this section of the report provide important information about the strengths and weaknesses of the workshop.

Teachers were also asked to rate the value of various workshop activities in contributing to their use of NGS Kids Network in the classroom. Responses for the activities were very positive. Ratings for other administrative and logistical aspects of the program were also positive, with the highest marks going to the knowledgeable, professional, and enthusiastic presenter(s) and the assistance provided by program administrative staff. 
Effects of Program Participation on 1994 NGS Kids Network Participants

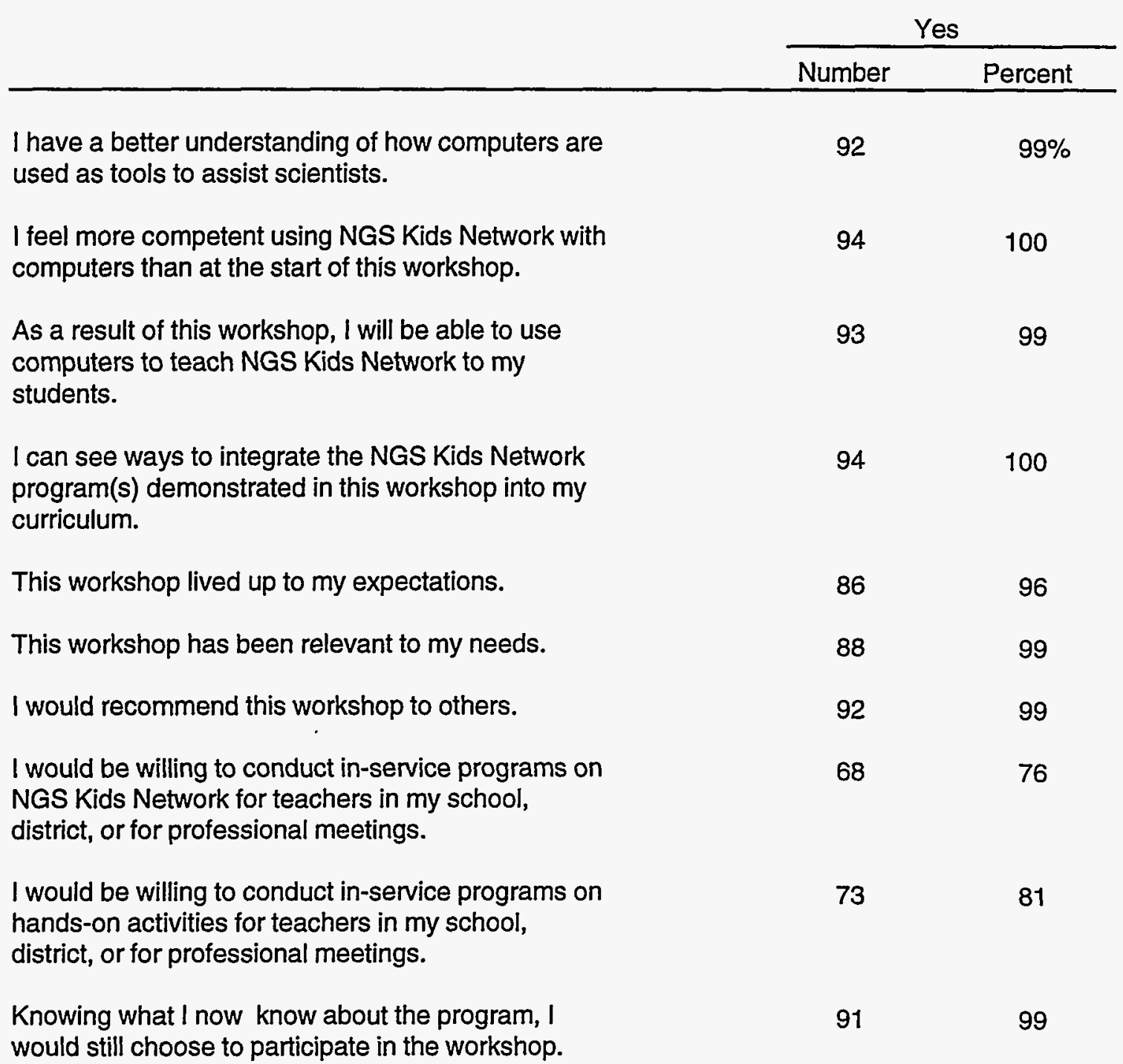

Note: n's for these items ranged from 89 to 94 responses. 


\section{How Workshop Is Expected to Contribute to Classroom Use by 1994 NGS Kids Network Participants}

\begin{tabular}{lcccc} 
& \multicolumn{3}{c}{ Percentage Distribution } \\
\cline { 2 - 5 } & $\begin{array}{c}\text { Little } \\
\text { Value }\end{array}$ & $\begin{array}{c}\text { Moderate } \\
\text { Value }\end{array}$ & $\begin{array}{c}\text { Much } \\
\text { Value }\end{array}$ & $\begin{array}{c}\text { Not } \\
\text { Applicable }\end{array}$ \\
\hline Overall workshop participation & $0 \%$ & $4 \%$ & $96 \%$ & $0 \%$ \\
Laboratory visits and field trips & 4 & 16 & 80 & 0 \\
Hands-on activities & 0 & 9 & 91 & 0 \\
Training sessions & 0 & 10 & 90 & 0 \\
Computer lab time & 0 & 11 & 89 & 0
\end{tabular}

Note: $n=93$ responses.

\section{Evaluation of Other Aspects of Program by 1994 NGS Kids Network Participants}

\begin{tabular}{lcccc} 
& \multicolumn{3}{c}{ Percentage Distribution } \\
\cline { 2 - 5 } & $\begin{array}{c}\text { Needs } \\
\text { Improvement }\end{array}$ & Good & $\begin{array}{c}\text { Very } \\
\text { Good }\end{array}$ & $\begin{array}{c}\text { Not } \\
\text { Applicable }\end{array}$ \\
\hline Program administration & $1 \%$ & $17 \%$ & $81 \%$ & $1 \%$ \\
Advance communication & 12 & 23 & 61 & 4 \\
Availability of resources & 1 & 17 & 81 & 1 \\
Assistance provided by program staff & 0 & 5 & 94 & 1 \\
Objectives of workshop clearly stated & 1 & 13 & 86 & 0 \\
Objectives of workshop met & 1 & 15 & 84 & 0 \\
Presentation clear and easy to follow & 2 & 13 & 85 & 0 \\
Presenter knowledgeable about NSG Kids Network & 0 & 3 & 97 & 0 \\
Professional and enthusiastic presenter & 1 & 4 & 95 & 0 \\
Involvement of audience in discussions and learning & 1 & 8 & 90 & 1 \\
activities. & & & &
\end{tabular}

Note: n's for these items ranged from 91 to 92 responses. 


\section{Comparison of Responses Before and After 1994 NGS Kids Network Program}

For purposes of comparison, certain items were asked on both the entry and exit questionnaires. The following table illustrates differences in pre- and post-program responses in the ways the teachers rated their knowledge, understanding, and interest in science/mathematics/technology as well as their awareness of job opportunities and training in these areas. In all instances, the mean ratings were higher after the program than before. In addition, for all six items, paired t-tests on the entry and exit means showed a statistically significant difference at the .005 level. In order to determine if such effects are long-lasting, a follow-up comparison will be conducted at a later point in time.

\section{Comparison of Responses for 1994 Participants Before and After NGS Kids Network Program}

\begin{tabular}{|c|c|c|c|c|c|c|c|c|c|}
\hline \multirow{2}{*}{$\begin{array}{l}\text { How teachers rate the following } \\
\text { (with 1=Low to } 7=\text { High): }\end{array}$} & & \multirow[b]{2}{*}{$\begin{array}{l}\text { Mean } \\
\text { Rating }\end{array}$} & \multicolumn{7}{|c|}{ Percentage Distribution } \\
\hline & & & $1=$ Low & 2 & 3 & 4 & 5 & 6 & $7=$ High \\
\hline $\begin{array}{l}\text { My knowledge about research and } \\
\text { the application of science/ } \\
\text { mathematics/technology outside } \\
\text { the classroom }\end{array}$ & $\begin{array}{l}\text { Entry } \\
\text { Exit }\end{array}$ & $\begin{array}{l}4.0 \\
5.1\end{array}$ & $\begin{array}{l}6 \% \\
0\end{array}$ & $\begin{array}{l}7 \% \\
2\end{array}$ & $\begin{array}{c}18 \% \\
9\end{array}$ & $\begin{array}{l}35 \% \\
16\end{array}$ & $\begin{array}{l}22 \% \\
35\end{array}$ & $\begin{array}{l}7 \% \\
29\end{array}$ & $\begin{array}{l}5 \% \\
9\end{array}$ \\
\hline $\begin{array}{l}\text { My knowledge about current } \\
\text { scientific/mathematics/technology } \\
\text { research and issues }\end{array}$ & $\begin{array}{l}\text { Entry } \\
\text { Exit }\end{array}$ & $\begin{array}{l}3.8 \\
5.0\end{array}$ & $\begin{array}{l}7 \\
0\end{array}$ & $\begin{array}{r}10 \\
3\end{array}$ & $\begin{array}{l}24 \\
11\end{array}$ & $\begin{array}{l}26 \\
16\end{array}$ & $\begin{array}{l}21 \\
33\end{array}$ & $\begin{array}{l}10 \\
29\end{array}$ & $\begin{array}{l}2 \\
8\end{array}$ \\
\hline $\begin{array}{l}\text { My understanding of the role of } \\
\text { science/mathematics/technology } \\
\text { in finding solutions to national } \\
\text { problems }\end{array}$ & $\begin{array}{l}\text { Entry } \\
\text { Exit }\end{array}$ & $\begin{array}{l}4.3 \\
5.3\end{array}$ & $\begin{array}{l}3 \\
0\end{array}$ & $\begin{array}{l}7 \\
2\end{array}$ & $\begin{array}{r}21 \\
6\end{array}$ & $\begin{array}{l}25 \\
12\end{array}$ & $\begin{array}{l}19 \\
32\end{array}$ & $\begin{array}{l}18 \\
37\end{array}$ & $\begin{array}{r}7 \\
11\end{array}$ \\
\hline $\begin{array}{l}\text { My understanding of the need to } \\
\text { integrate computers as tools in my } \\
\text { classroom }\end{array}$ & $\begin{array}{l}\text { Entry } \\
\text { Exit }\end{array}$ & $\begin{array}{l}5.6 \\
6.3\end{array}$ & $\begin{array}{l}3 \\
0\end{array}$ & $\begin{array}{l}3 \\
0\end{array}$ & $\begin{array}{l}8 \\
2\end{array}$ & $\begin{array}{r}10 \\
3\end{array}$ & $\begin{array}{l}12 \\
13\end{array}$ & $\begin{array}{l}21 \\
30\end{array}$ & $\begin{array}{l}43 \\
52\end{array}$ \\
\hline $\begin{array}{l}\text { My awareness of job opportunities } \\
\text { and training areas in science/ } \\
\text { mathematics/technology }\end{array}$ & $\begin{array}{l}\text { Entry } \\
\text { Exit }\end{array}$ & $\begin{array}{l}4.5 \\
5.3\end{array}$ & $\begin{array}{l}7 \\
2\end{array}$ & $\begin{array}{l}8 \\
3\end{array}$ & $\begin{array}{r}13 \\
3\end{array}$ & $\begin{array}{l}20 \\
13\end{array}$ & $\begin{array}{l}19 \\
31\end{array}$ & $\begin{array}{l}18 \\
26\end{array}$ & $\begin{array}{l}15 \\
22\end{array}$ \\
\hline $\begin{array}{l}\text { My interest in research and } \\
\text { applied science/mathematics/ } \\
\text { technology }\end{array}$ & $\begin{array}{l}\text { Entry } \\
\text { Exit }\end{array}$ & $\begin{array}{l}5.1 \\
5.8\end{array}$ & $\begin{array}{l}2 \\
0\end{array}$ & $\begin{array}{l}8 \\
1\end{array}$ & $\begin{array}{l}7 \\
1\end{array}$ & $\begin{array}{l}14 \\
16\end{array}$ & $\begin{array}{l}17 \\
15\end{array}$ & $\begin{array}{l}27 \\
32\end{array}$ & $\begin{array}{l}25 \\
35\end{array}$ \\
\hline
\end{tabular}

Note: $n$ 's for these items ranged from 92 to 98 responses and includes all data for each item reported by participants on entry and exit forms. 


\section{Summary of Open-Ended Comments}

The exit questionnaire also contained six open-ended questions to which teacher-participants responded candidly. Participants were asked about the strengths and weaknesses of the workshop and how it could be improved. They were also asked if the workshop provided enough information to enable them to use the NGS Kids Network in their classrooms.

\section{What were the major strengths of the workshop?}

The most frequent response to this question was the enthusiasm and knowledge of the presenter, which was cited by over half of the teachers as a major strength of the workshop. One teacher noted the benefit of "a knowledgeable presenter who is currently teaching and understands class flow, management, and motivation," while others responded "instructors were very good about patiently explaining each step," or "the excellent, professional instructors were so helpful, and made sure that we left the workshop fully informed!"

The time spent on computers, hands-on activities, the NGS Kids Network program and materials, and the field trips were also frequently identified as strengths (by one-third to one-half of the teachers). Typical comments included, for example, "I feel much more comfortable with the computer, and now I know how to telecommunicate!" and "I really feel I know the program because of our practice time and I liked the field trips that brought reality in!" Teachers were impressed with the NGS Kids Network itself, noting "the workshop material was very relevant, and I can integrate this whole network into by classroom beautifully." Other strengths mentioned by teachers included the time to share ideas with others and the opportunities to learn about telecommunications network.

\section{What were the major weaknesses of the workshop? In what ways could the workshop be improved?}

The most frequently cited weaknesses of the workshop were lack of organization and prior information about weather conditions, supplies needed, and transportation for field trips, cited by about one-fourth of the teachers. Teachers recommend "buses or vans for transportation would have been helpful for field trips" because "out-of-town teachers would feel more comfortable and less anxious." Some teachers reported "unclear directions" to field trips and suggested "better planning of field trips so we know what to expect —-hats, sunglasses, pens, papers, etc."

Interestingly, the second most often cited weakness involved the length of the program, mentioned by 1 out of 5 teachers. The 13 teachers who perceived that the workshop was too condensed were contradicted by the 5 teachers who perceived that the program needed to be condensed. Perhaps this comment explains part of the contradiction: "More days would be good, but I don't know if I could take in more!" 
Other weaknesses noted were cited by only 5 to 9 teachers; however, they are constructive ideas in terms of future improvements to the workshop. Some teachers felt that the computer training was specific to MAC users, and that IBM-specific information would have been helpful. Several teachers were frustrated by the basic level of instruction on the computers and the lack of adequate equipment in some computer labs. One teacher made the following suggestion: "We need to be more homogenous in our incoming computer skills." The disparate backgrounds of the participants caused frustration with some participants noting presentations "moved too slow," while others expected them "to be geared to the level of the audience."

\section{Do you feel that enough information was provided to help you use NGS Kids Network comfortably? Why or why not?}

About 9 out of 10 responses to this item were positive. The "yes" responses typically stated "we got to practice several times," or "we spent much time on the computers and thoroughly went through the curriculum," or "this is the best, most practical workshop that I have ever attended," or "I learned so much and am so excited to share my info with my class." Several comments such as "I have a good overview and some supplemental activities, and some hands-on experience with the software; I think we can take the manual and go with it," and "I feel comfortable, especially with the assistance available through the Hot Line and local personnel." A few of the responses were neutral. Many stated that they were "pretty comfortable," but they needed to reserve judgment until next fall when they actually tried to use the program with their students, but that the workshop provided "enthusiasm and confidence." "Teaching does not have to be dull. Put some life and fun into it and see how far all of us can go. What a bright future we have." This question merits repeating on the follow-up questionnaire so that former participants can report based on their actual experiences trying to use the NGS Kids Network. One teacher even noted, "If I find that I didn't get enough, I will discuss it at our follow-up meeting in January." 


\section{Appendix A}

\section{Entry Questionnaire}




\section{DOE/NGS KIDS NETWORK TEACHER INSTITUTES \\ 1994 Entry Form}

(lab)

(Please print responses in black ink.)

Date:

\section{GENERAL INFORMATION}

1. Your Name:

$$
\text { (First) }
$$

Home Address:

$$
\text { Zip: }
$$

Home Phone:

2. Name of School:

School Address:

Phone:

Name of Principal:

3. Sex: $\square$ 1. Male $\square$ 2. Female

4. Racial/ethnic background (optional):

1. American Indian or Alaskan Native

2. Asian or Pacific Islander

3. Black, not Hispanic

4. Caucasian, not Hispanic

5. Hispanic

5. Date of birth: $\frac{}{\text { (month) }} / \frac{1}{\text { (day) }} / \frac{19}{\text { (year) }}$

\section{EDUCATIONAL INFORMATION}

6. Level of highest degree earned:

1. B.S./B.A./B.Ed.

2. M.S./M.A./M.Ed.

3. Ed.S.

4. Ed.D.

5. Ph.D. or other doctorate

6. Other, please specify 
7. Are you currently working toward an advanced degree?

\section{Yes}

2. No

7a. If YES, what degree are you pursuing?

(Please check only one response.)

\section{M.S./M.A./M.Ed.}

2. Ed.S.

3. Ed.D.

4. Ph.D. or other doctorate

5. Other, please specify

8. Number of credit hours earned beyond your highest degree:

Semester hours

Quarter hours

9. Major field of study of your baccalaureate degree (check only one):

1. Elementary Education

2. Middle School Education

3. Education

4. Psychology

5. Humanities

6. Social Sciences

7. Mathematical Sciences

8. Computer and Information Sciences

9. Engineering

10. Biological Sciences

11. Earth, Environmental and Marine Sciences

12. Chemistry

13. Physics and Astronomy

14. Agricultural Sciences

15. Other, please specify 
III. TEACHING ACTIVITIES DURING YOUR MOST RECENT TEACHING ASSIGNMENT.

Please respond to items in this section based on your teaching activities during the past academic year.

10. At what level(s) were you teaching? (Check all that apply.)

1. High School

2. Middle/Junior High School

3. Elementary School (Including Kindergarten)

4. Other, please specify

10a. How many years of full-time teaching (through the past academic year) have you completed?

10b. How many years of part-time teaching (through the past academic year) have you completed?

11. Have you been responsible for conducting in-service or workshop activities during the past academic year?

\section{Yes}

2. No

11a. If YES, how many?

in-service or workshop activities

11b. If YES, what kinds?

12. Have you made presentations to professional groups during the past academic year?
1. Yes
2. No

12a. If YES, how many?

$$
\text { presentations to professional groups }
$$

12b. If YES, what professional groups? 
13. Please supply the following demographic information for your school.

13a. Approximately what percentage of the community in which your school is located is:

Urban $\%$

Suburban $\%$

Rural $\%$

13b. At your school, approximately what percentage are minorities?

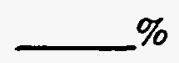

14. At your school, are there subject matter departments (e.g. math departments, science departments)?

1. Yes

2. No

15. List the types of topics you teach in your science classes:

16. List the types of topics you teach in your mathematics classes:

17. List the types of topics you teach in your technology (including computers) classes:

18. For the following subjects, please indicate if integrated with other topics in your teaching:
a. Science
$\square$ 1. Yes
2. No
b. Mathematics
1. Yes $\square$ 2. No
c. Technology
$\square$ 1. Yes
2. No 
19. Use of computers: (Check all that apply.)

1. No use of computers

2. Teacher use:

Classroom management (grades, scheduling, etc.)

Word processing

Other, please specify

3. Student use:

Drill and practice

Networking (communications)

Games

Interactive video

Individualized lesson plans

Special projects

Other, please specify

4. Problems with computer use:

No problems

Lack of equipment/software for teacher use

Lack of equipment/software for student use

Lack of technical support

Lack of teacher training for use of computers

Other, please specify

20. Approximately what percentage of your time spent on planning and classroom management involves computer use?

Percentage of Time $\%$ Not Applicable

21. Approximately what percentage of student learning time involves computer use?

Percentage of Time $\%$ Not Applicable

22. Approximately how many total students were enrolled in your science/mathematics/technology classes?

Total Number of Students

Not Applicable

(please continue) 
23. Approximately how many of your students completed projects for science fairs?

Number of Students

Not Applicable

24. Approximately how many students completed independent research projects (other than projects for science fairs) under your supervision?

Number of Students

Not Applicable

25. Approximately what percentage of time was devoted to student laboratory activities (including activities that are conducted in the regular classroom) in science/mathematics/technology classes you taught?

Percentage of Time $\%$

Not Applicable

26. Approximately what percentage of time was devoted to demonstration experiments in your science/mathematics/technology classes?

Percentage of Time

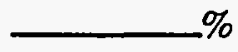

Not Applicable

27. How often do you use each of the following techniques in teaching your science/mathematics/ technology classes? Please circle a number in the appropriate column to indicate your response. If a technique does not apply to your classes, please circle NA for "Not Applicable."

$\begin{array}{lllll}\text { Less } & \text { At } & \text { At } & & \\ \text { Than } & \text { Least } & \text { Least } & \text { Just } & \text { Not } \\ \text { Once a } & \text { Once a } & \text { Once a } & \text { About } & \text { Applic- } \\ \text { Month } & \text { Month } & \text { Week } & \text { Daily } & \text { able }\end{array}$

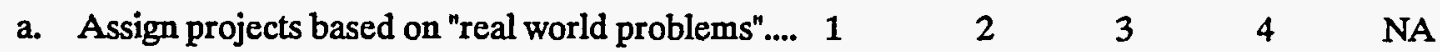

b. Assign teams to work on assignments.

1

2

3

$4 \quad$ NA

c. Use writing as a tool for student learning in my classroom. 1

\title{
3
}

$4 \quad$ NA

d. Integrate math, science, and technology in my teaching. 1

e. Assign oral reports or presentations to students... 1

$\begin{array}{llll}2 & 3 & 4 & \text { NA } \\ 2 & 3 & 4 & \text { NA } \\ 2 & 3 & 4 & \text { NA } \\ 2 & 3 & 4 & \text { NA } \\ 2 & 3 & 4 & \text { NA } \\ 2 & 3 & 4 & \text { NA } \\ 2 & 3 & 4 & \text { NA } \\ 2 & 3 & 4 & \text { NA }\end{array}$

f. Provide students with hands-on laboratory experiences 1

g. Counsel students on possible careers in math, science, or technology.

\author{
1
}

h. Arrange field trips for students

1

i. Bring guest speakers into the classroom. 1

j. Conduct scientific demonstrations for students...... 1

k. Use team teaching or other collaborative efforts.. 1 


\section{GENERAL ATTITUDES}

28. Please rate each of the following by circling a number from 1 to 7 to indicate your response.

a. My knowledge about research and the application of science/mathematics/technology outside the classroom

$\begin{array}{lllllllll}\text { No knowledge } & 1 & 2 & 3 & 4 & 5 & 6 & 7 & \text { Much knowledge }\end{array}$

b. My knowledge about current scientific/mathematics/technology research and issues

$\begin{array}{llllllllll}\text { No knowledge } & 1 & 2 & 3 & 4 & 5 & 6 & 7 & \text { Much knowledge }\end{array}$

c. My understanding of the role of science/mathematics/technology in finding solutions to national problems

$\begin{array}{llllllllll}\text { No understanding } & 1 & 2 & 3 & 4 & 5 & 6 & 7 & \text { Thorough understanding }\end{array}$

d. My understanding of the need to integrate computers as tools in my classroom

$\begin{array}{llllllllll}\text { No understanding } & 1 & 2 & 3 & 4 & 5 & 6 & 7 & \text { Thorough understanding }\end{array}$

e. My awareness of job opportunities and training areas in science/mathematics/technology

$\begin{array}{llllllllll}\text { No awareness } & 1 & 2 & 3 & 4 & 5 & 6 & 7 & \text { Much awareness }\end{array}$

f. My interest in research and applied science/mathematics/technology

$\begin{array}{lllllllll}\text { No interest } & 1 & 2 & 3 & 4 & 5 & 6 & 7 & \text { Much interest }\end{array}$

g. My confidence in teaching my science/mathematics/technology classes

$\begin{array}{lllllllll}\text { No confidence } & 1 & 2 & 3 & 4 & 5 & 6 & 7 & \text { Much confidence }\end{array}$

h. My confidence in discussing science/mathematics/technology applications with my students

$\begin{array}{lllllllll}\text { No confidence } & 1 & 2 & 3 & 4 & 5 & 6 & 7 & \text { Much confidence }\end{array}$

i. My confidence in supervising science projects of my students

$\begin{array}{lllllllll}\text { No confidence } & 1 & 2 & 3 & 4 & 5 & 6 & 7 & \text { Much confidence }\end{array}$

j. My confidence in making presentations at in-service meetings

$\begin{array}{lllllllll}\text { No confidence } & 1 & 2 & 3 & 4 & 5 & 6 & 7 & \text { Much confidence }\end{array}$

k. My confidence in interacting with peers on scientific matters

$\begin{array}{llllllllll}\text { No confidence } & 1 & 2 & 3 & 4 & 5 & 6 & 7 & \text { Much confidence }\end{array}$

Thank you for sharing your thoughts and ideas about the program. 
Appendix B

1994 Exit Questionnaire 
I. GENERAL INFORMATION

1. Your Name:

Home Address:

Zip:

Home Phone:

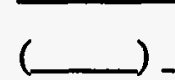

\section{ASSESSMENT OF PROGRAM}

2. In what ways has participating in the program affected you? (Please check the appropriate box beside each statement below.)

a. I have a better understanding of how computers are used as tools to assist scientists.

b. I feel more competent using NGS Kids Network with computers than at the start of this workshop.

c. As a result of this workshop, I will be able to use computers to teach NGS Kids Network to my students.

d. I can see ways to integrate the NGS Kids Network program(s) demonstrated in this workshop into my curriculum

e. This workshop lived up to my expectations.

f. This workshop has been relevant to my needs

g. I would recommend this workshop to others

h. I would be willing to conduct in-service programs on NGS Kids Network for teachers in my school, district, or for professional meetings.

i. I would be willing to conduct in-service programs on hands-on activities for teachers in my school, district, or for professional meetings.

j. Knowing what I now know about the program, I would still choose to participate in the workshop. 
3. Please rate each of the following by circling a number from 1 to 7 to indicate your response.

a. My knowledge about research and the application of science/mathematics/technology outside the classroom

$$
\begin{array}{llllllllll}
\text { No knowledge } & 1 & 2 & 3 & 4 & 5 & 6 & 7 & \text { Much knowledge }
\end{array}
$$

b. My knowledge about current scientific/mathematics/technology research and issues

$$
\begin{array}{llllllllll}
\text { No knowledge } & 1 & 2 & 3 & 4 & 5 & 6 & 7 & \text { Much knowledge }
\end{array}
$$

c. My understanding of the role of science/mathematics/technology in finding solutions to national problems

$\begin{array}{llllllllll}\text { No understanding } & 1 & 2 & 3 & 4 & 5 & 6 & 7 & \text { Thorough understanding }\end{array}$

d. My understanding of the need to integrate computers as tools in my classroom

$$
\begin{array}{llllllllll}
\text { No understanding } & 1 & 2 & 3 & 4 & 5 & 6 & 7 & \text { Thorough understanding }
\end{array}
$$

e. My awareness of job opportunities and training areas in science/mathematics/technology

$$
\begin{array}{llllllllll}
\text { No awareness } & 1 & 2 & 3 & 4 & 5 & 6 & 7 & \text { Much awareness }
\end{array}
$$

f. My interest in research and applied science/mathematics/technology

$$
\begin{array}{lllllllll}
\text { No interest } & 1 & 2 & 3 & 4 & 5 & 6 & 7 & \text { Much interest }
\end{array}
$$

4. Please rate the value of each of the following on its contribution to your effectiveness in using the NGS Kids Network in your classes. Circle a number to the right of the item to indicate your rating on the following basis:

$1=$ Little or no value

2 = Moderate value

3 = Much value

NA $=$ Not applicable

Little Moderate Much Not

Value Value Value Applicable
a. Overall workshop participation

23
$3 \quad \mathrm{NA}$
b. Laboratory visits and field trips

2
c. Hands-on activities.

2
3 NA
d. Training sessions

2
3 NA
e. Computer lab time.

2
3 NA
$3 \quad \mathrm{NA}$

(please continue) 
5. Please evaluate other aspects of the program on the following basis:

$$
\begin{aligned}
& 1=\text { Needs improvement } \\
& 2=\text { Good } \\
& 3=\text { Very good } \\
& \text { NA }=\text { Not applicable }
\end{aligned}
$$

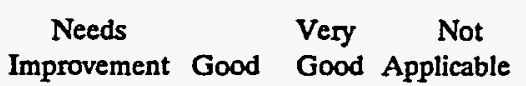
a. Program administration.
. .1
23
NA
b. Advance communication
.1
c. Availability of resources .1
23
23
23
23

23

23

23
23
2
e. Objectives of workshop clearly stated...................................................1
f. Objectives of workshop met...................................................................... 1
g. Presentation clear and easy to follow..

1
h. Presenter knowledgeable about NGS Kids Network........................1
i. Professional and enthusiastic presenter.............................................1
j. Involvement of audience in discussions and learning activities... 1

23 NA

6. On a scale of 1 to 10 , with 1 representing very dissatisfied and 10 representing very satisfied, how would you rate your experience in the workshop?

7. What were the major strengths of the workshop?

8. What were the major weaknesses of the workshop? How could the workshop be improved?

9. Do you feel that enough information was provided during the workshop to help you use NGS Kids Network comfortably? Why or why not?

Thank you for sharing your thoughts and ideas about the program. 
Appendix C

1994 Responses to Open-Ended Questions on Exit Form 


\section{What were the major strengths of the workshop?}

The extra insights on teaching ideas. The knowledge gained from field trips, classmates, the instructor, and the materials provided.

The hands-on as the presenter walked you through the program, the presenter constantly encouraged you to "do not panic," "it will all be all right, keep trying," "you can do it," and "you can telecommunicate if you don't quit."

The computer training. The knowledge of the presenter in sharing his ideas. The wonderful materials that I received. This (the materials) was truly helpful.

Background info-leading into the program gave me a solid base. I really feel I know the program because of our practice time. Iliked the field trips, they really brought reality in!

Knowledge and helpfulness of the leadership were strengths. The relaxed atmosphere was enjoyed, as well.

The knowledge and patience of the presenter, thoroughly going through each lesson step by step, sharing of teacher ideas, spending time using the actual program, the field trips, and materials given were wonderful.

Outstanding presentation and field trips. Outstanding materials to supplement my "Too Much Trash" curriculum and other units which I teach. I feel much more comfortable with the computer and now I know how to telecommunicate! The students can communicate with other societies from all over the world, and this might give them a better understanding of different cultures.

The instructor worked with us individually or in small groups on the computer. He told us to ask questions and for help at anytime. He reminded us that there are no "dumb questions." I have enjoyed exchanging ideas with other teachers. Our lesson exchange day was really helpful.

A knowledgeable presenter who is currently teaching and understands class flow management and motivation. Lesson-by-lesson planning. Computer time to become familiar with the computer. Time and help to plan my own unit.

Having a leader that had used the program with students in a classroom. Materials and experiences available to support the goals of the program.

Getting a thorough understanding of how to use the software. Learning about and visiting resource people and places. Sharing related teaching ideas.

Materials provided (especially the unit). Working on the computers.

The field trips were most important because they made me aware of our very serious waste problem. I intend to use this information in planning and teaching lessons to my students. 
Hands-on activities and field trips.

The hands-on experiences and time at computers. The eye-opening field trips. The time allotted for curriculum development between teams.

Being able to communicate to me so that I have a knowledge of how to use the NGS Kids Network at my school and cover the topic of trash and waste so that I could gain knowledge on that topic.

Time to actually make a practical/personal action plan. Plenty of computer time. Going through the curriculum.

Computers were actually used as a learning tool often. Sharing ideas, to supplement the unit between fellow teachers. Time spent for actual planning out the units. Going over the curriculum thoroughly.

Presenter was very knowledgeable and well organized. The staff was very friendly. The personnel, the field trips, and the hands-on activities.

The opportunity to be at a university where things were available (solar car, Iowa thin files, etc.) Opportunity to use computers to learn software, opportunity for hands-on.

Computer experiences, learning the software, learning about America Online, hands-on activities.

Exposure and practice with the software. Handouts would be given, time to work on the unit, and lesson plans for our individual classrooms.

Lots of hands-on activities. Opportunity to dialog with instructor and participants.

Enthusiasm and knowledge of presenters. Variety of activities and materials.

Computer time, introduction to knowledge of technology, and a true sense of direction in technology.

Activities based. Helpful attitudes. Much information made available.

Enthusiastic presenters.

Explanations of how to use computers.

Hands-on activities.

The hands-on activities and field trips were excellent.

Participating in some of the activities we will be actually doing. Resources, resources. Computer time and introduction. 
Field trip and teacher interaction.

Doing the unit. Variety of activities.

The excellent, professional instructors. They were so helpful and sure that we left the workshop fully informed.

The enthusiasm of presenters, the field trips, and America Online ideas.

The atmosphere and willingness to answer any questions asked.

All aspects of the Solar Energy program were covered. The staff were all so very kind and helpful.

Involvement by the participants. Enthusiastic instruction. Variety of activities.

Activities we did. I'll understand and appreciate my students' efforts.

Excellent instructors and materials.

Field trips.

Learning to use a total cross curriculum unit that is science geared. Hearing other people tell the importance of computers in the classroom.

Guest speakers and hands-on computer activities.

Videos, hands-on, one speaker, and the leader.

Computer time and presenters' knowledge.

Using the computer. Your patient assistance and answering of questions. Making inexpensive weather instruments. Class discussion.

Computer time.

How to use computer materials. Iloved all the materials-lessons, atlas, shirts, lunch.

Size of class, activities, field trips, speakers, and expert attentive help.

Hands-on experience.

Instructors were very good about patiently explaining each step.

Knowledge of resources available, networking. Hands-on computer time. Going through aspects of the curriculum.

Friendly, helpful presenters as well as fellow teachers. 
Great scientists. Computer lab.

Outside speakers, computer time, and classroom interaction.

Computer time, presentations by scientists, and hands-on activities.

Enthusiastic, patient presenters, great resources, shared experiences, opportunities to interact with other teachers and contacts across the state.

Hands-on technology experiences, nice resources, comfortable learning environment.

Lots of hands-on. Clear instructions.

The hands-on activities and computer lab times.

Presenters, field trips, resources.

The major strength of the workshop was to be able to network with others.

Again, the variety of activities.

The instructor is a major strength of the workshop; the workshop material was very relevant and I can integrate this whole network into my classroom beautifully.

Field trips, hands-on computer work.

Working with computers.

The lab activity time and hands-on activities. Exchange of ideas with other professionals and teachers.

Presenter, information available about NGS Kids Network. Good practice using units in general.

Telecommunications, activities, materials, and field trips.

Hands-on opportunities to experiment and learn, field trips to solar energy sites, exchange of information with colleagues, and resources ready to use.

Computer lab time and field trips. The instructor was excellent as a presenter.

The instructor, field trips, computer time, and materials.

Enthusiasm of instructor. Hands-on activities.

Knowledgeable presenters - patience and understanding, field trips, availability of information given to us, small number of people in workshop for more needed attention for us, freebies. 
Presenters' patience and knowledge of material.

Time to use and learn about computers and programs. Meeting other teachers and sharing great ideas. Helpful knowledgeable presenters and support people.

Background information - exposure to facilities outside of my area. Being able to work with the computer and ask questions about program. Classroom background and management techniques shared. Good and relevant handouts.

Computer lab time. Field trips.

The presenter was very, very knowledgeable.

The great variety of information at our disposal, the excellent field trips.

The field trips were valuable experiences. I especially enjoyed the trip to the watershed.

The instructor made this workshop so much fun, organized, knowledgeable. Inow feel confident about presenting the program to my class.

The instructor was an enthusiastic, intelligent presenter. Information was organized in an exciting manner. To have the workshop at a lab made the atmosphere geared toward science, giving teachers an idea of possible scientific careers. Vocabulary, bulletin boards, atmosphere all added interest.

Good presenter. Hands-on use of computer.

I thought that the hands-on activities and the site visits were extremely beneficial.

Have someone who has used the program and is a teacher, who knows the roadblocks we run into in the classroom and schools.

Computer learning. Teacher input on strategies.

Excellent availability of resources and teaching aids. Extremely enthusiastic presenter. Pertinent and informative field trips. Wealth of information, well organized.

Materials and information covered a broad range so that you could do as much or as little as you wanted to do in your classroom.

The ability to see how the entire program came together, including the field trips. 


\section{What were the major weaknesses of the workshop? How could the workshop be improved?}

The computer lab was not as advanced as I would have expected. It would have been nice to travel in vans as a group to field trips.

The starting time was a little early for me. Perhaps 8:00 to 8:30-I realize the ending might need to be changed. Perhaps you could add one day.

To be able to be at one place for the entire week with facilities to best accommodate the program. Group transportation to field trips.

Only one computer platform was available for instructional purposes and practice. Buses for transportation would have been helpful for field trips-expensive, too. For future workshops, Internet instruction would be great.

Use of computer time using Internet, availability of both DOS and MAC, a chance to view or share other computer programs that would enhance "Too Much Trash."

No. I didn't know that I was going to do the "Too Much Trash" unit. Had I known, I would have brought other information from school to help develop my unit.

I think a van or bus should be provided for the field trips. Out-of-town teachers would feel more comfortable and less anxious.

Buses or transportation provided in unfamiliar cities for out-of-towners for the field trips. Do have field trips, just help the out-of-towners. More time could be given to the day we spent on the lesson plans. The instructor had taught NGS Kids Network units before and was a valuable resource. His hints in going over the lessons were great, and I think he felt rushed.

Transportation for field trips should be provided.

Filling out the same evaluation form each day was hard after a while.

I am unable to identify any weaknesses at this time. It was an excellent workshop. The presenter was excellent.

I think more active participation from participants during presentations would be most helpful.

Not centrally located.

Not applicable, just keep up the good work.

The computers were slow running, and there were no printers.

Day two was very profitable because we actually went step by step through the curriculum. I wish we would have gone through more slowly. A van/bus for field trips would have been helpful for those of us from out of town. 
The one thing I would improve is the way to order the NGS Kids Network software. It was very confusing to know what to order and how to order it. I did not understand about the telecommunication time when I was expected to have the order in. I appreciate the staff taking so much time explaining it to me.

It would have been helpful for those out-of-town to have had a van or school bus for field trips.

Computer lab time was not always productive. Use the Internet at a better time of day. Give a quick overview of using NGS Kids Network right at first.

Computer lab, Internet—stop and go to something else when didn't work.

I think it could be condensed. Field trips to thin films long. A thirty-minute tour would have been great.

I really expected (from the advance materials) that we would be given time to work on the unit and lesson plans for our individual classrooms.

We commuted - very tiring - maybe you should stress advantages of staying on-campus, especially if more than 9:00 a.m. to 5:00 p.m. participation is required.

This could perhaps be consolidated into shorter workshop-or more time given during the week to develop other units we have purchased.

Not much, except break down computer time, and maybe one more time through the software.

Still not really sure about computer software use, but it will come.

Computer instruction was too basic. Classroom management needed.

More detail about solar car expectations and sooner.

Some terminology above my computer expertise.

We needed time to plan with the people from our school-implementation.

I would like a better initial "global glance" of what NGS Kids Network entails.

Some was too basic.

Solar thin film tour needs to be brought down to our level.

It would be difficult to improve. There was so much good about it. More days would be good, but I don't know if I could take in more!

We need to be more homogeneous in our incoming computer skills. We could spend less time on the intro video, etc., and more time on extra field trips. 
We spent a lot of time on our solar car. I would like to have had more information to read about NGS Kids Network before I came to the workshop.

It was not weakness of the instructor, but rather my own weakness of lack of computer knowledge. Had I felt more knowledgeable I could have learned more.

Maybe going through the program on computers and actually networking.

Work on computers first day.

I would have liked more individualized or small group work. Sometimes directions were not clear.

We have some time that moved too slowly. Some of it was weather related so equipment could not be used.

Too much lecture time in class.

Get IBMs to help those who will use them. Work through more of the exercises to demonstrate exactly how they will work. Organization in pre-program and setting and sticking to the schedule.

Too much lecture time.

Having a computer similar to ours available for learning. Computer use is too new for me to easily transpose information from one type to another.

Too much talk.

Lessons on teaching strategies and more sharing sessions, more hands-on activities.

The presenter was too loquacious. Time was wasted on side topics, i.e., "Mudd Puddles" (a book), etc. Shorten to three days. Don't talk more than one hour, then do a different activity.

By allowing participants to practice on the computers. It would be helpful if both types of computers could be used.

Lab presentations need to be geared to the level of the audience. Some were good speakers. Other presentations were not as successful. The meteorologist did not really explain his work or work environment in a relevant manner. He talked about his computer screen.

There needed to be more "hands-on" activities-less discussion.

Less lecture. More group work.

Too much lecture.

Too much lecture. 
Needed an IBM computer for those of us that will not have Macintosh computers.

Workshop could have been covered in 3 days.

Standing out in hot sun with very little shade.

The time-space, if the sessions would be longer.

Too hot for outdoor workshops.

I feel that there were no weaknesses with this workshop.

No IBM accessibility.

I feel divided-sometimes the workshop really dragged. This workshop could have been done in two full days minus the side trips, etc.

Unclear directions to our first field trip to Sandia Bay. Plan better.

It needs to be longer.

Directions and meeting places for field trips were very unclear, especially for people from out of town. Better planning of field trips, so we know what to expect, sunglasses, pens, paper, etc.

Make sure people know that all field trips will be outside and to prepare accordingly. A workshop T-shirt would be cool.

Coordination of activities. Have some activities planned in detail. It was hot out there, go early in the morning to some of these things.

No weakness, only at times had to stay in the sun a little longer than expected.

Improve communication.

Organization in terms of getting people on the base.

Not being able to work on a computer similar to the one I will be using at school. All computers might have been represented if only one.

The teacher's manual is not written in a manner that is easy to implement. It requires too much time for the teacher to gather the needed information to teach one lesson.

More field trips are needed.

More time on computers, and one computer for each participant. 
In the beginning, there was too much lecture time.

It was assumed that we had some background information about NGS Kids Network. Field trips should have been at the beginning to give a better understanding of concepts, terminology, for example, watershed, nitrates, phosphates, etc.

Communication: about the workshop-by chance I was fortunate to speak personally to someone at a course and learned about it, information about workshop was received the day we left, nothing was mentioned about clothes necessary for field trip to watershed.

Communication needs to be earlier and more specific (i.e., boots for streams, lab coats, etc., and insect repellent for meadows, woods, streams.)

I found some of the outside activities and speakers to be of little value for me.

I would have preferred more hands-on activities in the beginning of the workshop. Also, the site visits (especially watershed trip) could have been scheduled for earlier in the week.

There were no major weaknesses at all. The workshop could probably be improved only by having more time and a post meeting, about six months later to see how we all did.

Field trips to watershed, although interesting, was difficult for some people physically. Specimens could be brought to us for study perhaps.

The workshop could easily be extended for another week—too short.

Only limiting factor was poison ivy.

More time is needed for everything, perhaps two weeks. 


\section{Do you feel that enough information was provided during the workshop to help you use NGS Kids Network comfortably? Why or why not?}

Yes, I feel very confident about teaching this unit. I have gained knowledge and know how to completely use the program.

Yes. Plus the materials and the telephone numbers to call for additional help if and when needed.

Yes, I feel very comfortable and excited about using the NGS Kids Network.

Yes! The "Too Much Trash" program was thoroughly covered and we received many resources that will supplement the whole theme of this week.

Yes, definitely for MAC users. For those of us who have IBM platforms, we spent a lot of time spinning our wheels. There were other things for us, but practice would have been beneficial.

Yes, definitely. I feel I've had a chance to try out the program before applying it, but I feel comfortable in seeking resource people if needed.

Great job, we need more worthwhile workshops such as this one.

Yes.

Yes. I know I can call NGS Kids Network office if I have a problem.

Yes. I had an excellent presenter. He was knowledgeable, interesting, and enthusiastic. The staff was helpful and knowledgeable.

Yes.

Yes! We got to practice several times. Also, problem areas were pointed out along with possible solutions.

I feel that we had enough materials. If I find that I didn't get enough, I will discuss it at our followup meeting in January.

Yes. There was certainly enough information provided. We were given lots of information from presenters, materials, and through field trips.

Excellent workshop.

Yes.

Yes. The program was first explained with all objectives and goals. Then we were allowed to put these objectives and goals in order for our upcoming year. The work on the computer was the most valuable experience of all to me. 
Yes, because I can transfer my knowledge gained to others.

If feel the workshop provided appropriate information. I appreciate the availability of individual instruction time. This truly helped.

NGS Kids Network staff were very helpful.

Yes. We spent much time on the computers and thoroughly went through the curriculum.

Enough information was provided during the workshop. We also have information that we must use on our own time to help us when we use this unit in our classrooms. A vast amount of resources and materials was given to us.

Yes, drawback is my using a different computer.

Some things were confusing and wonder where fit in because have much background - as interest.

Yes, explained well and opportunity to practice and discuss.

Yes. Everyone was great and provided time to work with the software, also they were available during breaks and at the end of the day.

Yes, I have a good overview and some supplemental activities and some hands-on experience with the software. I think we can take the manual and go with it.

Yes.

Yes.

Pretty much, experience is the key. You gave us enthusiasm and confidence.

I'm glad I took this class. Many of my concerns were addressed.

Yes.

Yes, it gave me a knowledge base that will make me feel more secure and comfortable.

Yes. I think practicing in the workshop and before the actual start-up is essential.

I think so. Each unit will have some differences, but the components are the same. I'm worried more about troubleshooting difficulties and our modem, computer, and hypercard.

Sure.

Yes.

Yes. 
Yes.

Yes, every question was addressed.

Yes, I felt there was information about each area except the modem and its use. Probably this was familiar to everyone else.

Since I have three other people in my building who are familiar with the program, I know they will be willing and able to help me. You provided us with ample information.

Yes. And I have a co-teacher that has experiences in networking.

Yes. Loved it.

Yes. They also provided so much other information for us to use in all other subject areas. Good unit.

Yes.

Mostly there was more than enough information, but still would like more.

Attending this workshop has helped. I could not do the program without the explanations given since I know little about telecommunications. I still feel uncertain about the process, but with some effort, I hope I can put it together.

Yes. Presenter adequately answered all logistics questions which had worried me.

More information on how to use with my IBM machines.

Yes, met all my needs.

Yes.

Yes. For teachers using MAC.

Yes. What I learned will give me a good start.

The networking and resources brought to our attention were excellent.

To help me get started perhaps, but I am glad there were other people from my school attending the workshop. I'm sure I will have many questions.

Yes, but I won't feel really comfortable with it until I try it. It will be difficult to figure out the logistics of using it with four different classes. 
Yes. We need to try it first, but I know enough to get started.

Yes, presented very clearly.

My only worry is the difference between IBM and MAC.

Yes. This is my first teaching assignment, and I feel comfortable giving it a try.

Yes. The handouts and manuals are clear and thorough.

Yes, I had no knowledge of the NGS Kids Network; now I feel a little more comfortable with the program.

Yes, he showed us how to use the NGS Kids Network, and I feel comfortable about using it.

Yes, because of the ability to actually go through each step and actually be able to apply what was learned by doing hands-on activities.

Yes. Again, except for the lack of use with an IBM.

Yes. It is nice to move along with the presenter on the computer. It is hard to watch and listen without trying.

Yes, but would like to get even more.

Yes. It just needs to be for a longer time limit.

Definitely enough information. I just hope I can retain it all until I can apply it.

Yes.

Yes.

Yes, Ifeel comfortable especially with the assistance available through the Hot Line and local personnel.

Yes. The manuals appear to be written clearly so that with the hands-on work I did here, everything should go fine.

Yes. I suppose I'll find out for sure when I use the program.

Ihope.

Very much information was provided.

Definitely. 
Yes, I think we will be fine.

Good background information. Ineed to integrate it and adapt it to my area.

Yes.

Yes. Excellent materials.

Yes. I am simply hoping that my principal and school district will now support this program by giving us the necessary tools (computers, etc.) to carry on this work. This is the wave of the future, educationally speaking. Ihope my school district will be able to get aboard in time.

Yes. The lab time was especially helpful. I like being able to "play around" on the computer. I enjoyed plotting the latitude and longitude.

The computer disks need to be able to put a graph or map graphic in text (i.e., letters, etc.) The scientific instructions in the activities should be very specifically written, not only in the teachers manual, but also and very importantly on the activity sheets. There are too many variables on the activity sheet.

The sight of this location was an excellent choice. It is serene, easy to get to, and extremely interesting. The bulletin boards near the cafeteria were marvelous. I would love to be able to have a set of the 6 or 8 reasons for fusion energy and what is fusion energy. We teach a GEMS unit on atoms, and this would be such a marvelous bulletin board to initiate interest and information. I personally would like to know a lot more about this. I spoke to someone about this, but as of this moment, I have not heard anything. If this is possible, I would so appreciate you sending them to me. (The field trips and presentations were fabulous.) Ilearned so much and am so excited to share my information with my class. Thank you very much for an excellent five days. Also a tour of the lab would be excellent. I'm so happy the staff came down to speak about the lab. It was very nice to have the opportunity to meet and talk with such helpful and well-informed people. I spoke to them about the above.

Everyone here is so very helpful and friendly. It encourages our enthusiasm.

Yes, excellent. Comments: We had no notice in my area of this workshop, even though we have worked with Acid Rain for about eight years. NGS Kids Network should be able to be cut and pasted onto text. Maps/graphs on text. We were very interested in the bulletin boards on fusion (i.e., 8 Reasons for Fusion and the bulletin board next to it on fusion, pictures, information, etc.) We would be thrilled to have the 8 Reasons and other information for our classrooms. We use Lawrence Hall of Science GEMS and AIMS units to enhance our teaching of science, and the fusion information would be helpful. They gave us some rudiments of what is fusion, but a layman's pamphlet would be helpful (geared for 5th-grade students). A tour of the lab would have been great. 
I think I need more computer time.

Yes I do. We worked in the computer lab on a number of occasions. This was one of my major concerns. We also received an efficient amount of handouts to supplement the program.

There was more than enough information provided and shared among those at the workshop. I would suggest if NGS Kids Network had a hotline for tips that teacher could send in to tell different ways they have used it so it could be shared.

Yes.

Yes, because the presenter was so knowledgeable and enthusiastic. Also, there was a representative from National Geographic to answer questions about the program. Not only did I enjoy this workshop, I truly learned a great deal. Furthermore, I am leaving the workshop with the desire to find out even more about our water. Thank you.

Yes. Covered everything you need to know, plus gave you places to ask for help.

Yes, I am so grateful for all I have received. 


\section{Appendix D}

1994 Responses to Participant Evaluation of Daily Activity 


\section{ACTIVITY: INTRODUCTION - TOo Much Trash}

\section{August 1, 1994}

\section{Please write two or three sentences expressing your reaction to today's activity.}

I was looking forward to today and was not disappointed. I appreciated the introduction and background of information that was presented. I have a basic working knowledge of what this week will cover-Ilike that.

There is a lot of information for us to absorb. It is all very interesting.

It was a good introduction to the network.

Today's activities were very helpful in planning my program. I feel confident about beginning. I will enjoy using the program in my class.

It was enlightening, informative.

Presenting the week's agenda was an excellent idea. The hands-on computer time was most valuable. All of the resource materials are extra-special.

The activities were very informative. Inow have a better understanding of NGS Kidsnet. The kids are going to love it.

I am very excited about this material, and I can't wait to use it with my students. They will love it!

I enjoyed today's session even though it seemed to be a bit slow getting started. Enough information was given to make me excited to know about tomorrow.

This has been an exciting day. I feel a bit overwhelmed with the telecommunications part. I hope I can do everything on time.

I enjoyed learning about the many programs by NGS Kidsnet. I am going to use the gettingacquainted activity because it seemed to have been fun for everyone.

I liked the low-stress atmosphere created by the presenters. The time spent on the computer was excellent.

I was able to listen, understand the instructions, and load the computer. I was able to review data in the computer. I was able to get out of the computer. 
The morning session was mainly getting to know each other, which could have been accomplished in a short amount of time. I would rather have spent the time learning more about the NGS Kidsnet. I would also have gotten more out of computer time spent later if I had a software manual instead of just "playing with it."

I am very excited about the project. I am looking forward to working with my kids on this project.

I can't wait to set up my computer and boot up the program. I also have a better understanding of networking.

The afternoon was productive and high interest. The morning activities in some places moved slowly I was eager to learn more about the program. Perhaps the graphing activity would work better after we've sat at a computer for a while.

It seems that it was a slow start this morning. I really was expecting a faster pace and more intense hands-on workshop.

The afternoon session on computers was helpful. Morning seemed "long," but enjoyed introductions. Would rather have had a brief introduction and more time on computer. Only show one video.

I was extremely pleased about the materials given to teachers. The hands-on experience was very good because it allowed us as teachers an opportunity to learn, as well as make mistakes.

Enjoyed introductory activities. Hands-on computer usage was beneficial, was very beneficial. Plan for more participant involvement.

I thought it took an awful long time to really begin! (After lunch)

I would have preferred more time on the computer.

\section{Three important things l've learned are:}

I learned what NGS Kidsnet is all about. I now know that I have resources only a phone call away. I've learned some key concepts on the computer program.

About telecommunications, can be taught in any area, and it is beneficial to the children.

To start the program early, to be sure of the program and activities before teaching, how to sign-on and get started.

To load the program, to find my global address, to organize my lessons.

What telecommunication is, what it does, how to enter the program. 
The importance of teaching students ways to preserve our environment. How to get started on the computer. Providing samples of how students. share results with other students across the country!

How to find a global address. How learning can take place via computer. Insights into fun teaching.

How to begin networking with other classrooms. How to go about setting up my classroom to network. How to turn my kids on to science in a totally new way.

The setup of the network. The importance of preparation. The dedication of the staff and how necessary it will be for me to be equally dedicated.

Who class members are and what they are doing. That each teacher can make a difference. Science experiments will keep my students involved in their world.

How to install the program. How to get in and out of the desktop. Kids learn by doing.

Science covers everything.

How to operate the computer. How to go from one program to another. How to get out of the program.

How telecommunicating is accomplished. An appropriate and fun way for kids to learn graphs. How to integrate trash with social studies.

How the NGS Kidsnet works. How to install the program. Ilearned I needed Hypercard 2.1 for my progress.

Clearer picture of a "network." Understanding about the need for a Hypercard. International program - that my students can communicate with students from other countries.

Method of loading the program. Sending mail. Hands-on experience practice.

The materials with the information needed is included. Patience is necessary.

Symbols will not telecommunicate, what global address is all about, we have 120 minutes open for Kidsnet.

We can hook up with students all over our nation. Names of specific lessons to involve my students in. How to get started with NGS Kidsnet "Too Much Trash."

Video information was useful, especially emphasis on preparation using the "Hello Kit." Usage of computers. Start collecting materials that can be used. 
(Hypercard problems.) To load the program—misc problems. To begin "action plan."

What is needed to run the program, overview of the "Too Much Trash" program, what are the expectations.

\section{Two ideas or insights I would like to share with colleagues are:}

Networking is still new to our school. I would like to share what I've learned about it. I would also like to share the many types of programs available through NGS Kidsnet.

It makes a good interdisciplinary unit. It can be very beneficial to all.

Have a partner to plan with; share the workload.

I will share computer skills and software knowledge.

This program is an excellent one and can be used with any grade.

I intend to share ideas on how "Too Much Trash" can be integrated with other subjects.

Teaching does not have to be dull. Put some life and fun into it, and see how far all of us can go. What a bright future we have.

Use the computer as a teaching tool for scientific method and not just for games. There is a great need for more hands-on activities-find them and use them.

The importance of involving technology into subject area. The many facets "SCIENCE" covers.

Never too old to learn, trying new ideas brings enthusiasm into teaching.

This program is a way to get kids involved in learning. This program helps kids learn to work cooperatively.

Have more hands-on activities. Integrate subject areas as much as possible.

Never be afraid to try. Never give up.

Share ideas regarding the trash unit.

This program is a great way to include other disciplines in the activity.

I would love at some point to share this with other grade levels. Enthusiasm for a hands-on program.

Science is learned by active not passive involvement-subjects are interrelated. 
That every teacher is coming from a different school system or school with different things available. I would inform colleagues of different ways I have students research about scientific issues.

Great program if used correctly. Children like to be involved and receive some type of success or good feeling about something.

Environmental activities (i.e. EPA book). The program-I would love to see our whole grade level participate.

How they can use this program in their classroom. How to use the desktop.

\section{One action I will take tomorrow:}

One of my goals for tomorrow will be paying close attention to the lesson plans and looking for ways to implement additional activities for my situation.

Working harder on the computer.

Find out global address and sign-on information for sure, so that no problems occur when the unit begins.

Plan.

Use the computer to set up and become more familiar with using the NGS Kids Network.

I intend to explore all parts of the "Too Much Trash" program diskette.

Get into the computer to learn about "Too Much Trash."

I will verify my global address.

I will be organized and well-read so I can step in and participate.

Work on my lesson plan, work on computer program.

Start thinking about ways of introducing this unit to my kids.

Come early and practice on the computer.

To continue putting $100 \%$ into learning the computer network.

Keep building knowledge and ideas regarding this program. 
I will move around more.

I hope to experience "booting" up the program until I feel confident.

Spend more time on computer.

I will ask more questions of presenters, so that I am very clear about the NGS Kidsnet computer program.

Listen for ways cooperative grouping will be used.

I am very interested in going through the lessons.

More practice running the program on the computer using the "Too Much Trash" program.

\section{How will I translate this back to my classroom?}

Sharing with other teachers. Having practiced with the program prior to classroom. Hopefully I will be able to make it interesting and be of help as they pursue this research.

I will use it to help in motivating my children and team.

I will integrate it into my science and social studies curriculum. Ifeel it will greatly benefit the students.

I will begin to write my lessons and action plan.

I intend to use Mr. __'s format.

This will be integrated with my science, health, math, spelling, reading and writing, or language for a sixweek period. The question is, will the children be willing to go back to the traditional way of teaching. Hopefully, I will be able to do something like this all year.

I will use some of the ideas from the video. I love small group activities and peer-helping and -tutoring. The students will collect data, analyze it, and draw accurate (I hope) conclusions to share with other schools.

Attitudes are important, and I'll take an attitude of questioning, problem-solving, and application back to my class.

I can hardly wait to get started. I really care about the environment-I want my students to enjoy the project while learning to care for our world.

This is what I want to become more familiar with as the week progresses.

Better lesson planning and more hands-on activities. 
Throughout the year, we, as a class, will discuss the procedures and actually go through the process and do the experimenting and recording data even after the hours have expired.

It is still a process of discovery and analysis-I can't answer until the process is complete.

I know how I will interface it, however, I need to know more particulars.

I will use it only after planning-lessons and an action plan. I'll also use parents to help implement the program.

Plan ahead sufficiently. Work through and practice. Set up paperwork (children's notebooks, etc.), computer times, and collection times carefully.

Allow children to become more involved.

Science-use of computer and producing more hands-on activities for students.

I will be team teaching with a third-grade co-worker. We will be cooperative planning and pairing fifthand third-grade students with each other.

I love cooperative grouping and I am always looking for more techniques in using this method of working with children.

Iplan to utilize the networking and activities!!

Show them how to use the computer getting into desktop.

\section{I would rate this activity:}

Excellent, Iliked it a lot!

Okay.

Okay.

Excellent, I liked it a lot!

Excellent, I liked it a lot!

Excellent, Iliked it a lot!

Excellent, I liked it a lot! 
Excellent, I liked it a lot!

A bit better than okay.

Excellent, I liked it a lot!

Excellent, I liked it a lot!

Excellent, I liked it a lot!

Excellent, I liked it a lot!

Excellent, I liked it a lot!

Somewhere between okay and bad news, let's don't do this again.

Really somewhere in between excellent, I liked it a lot! and okay.

Better than okay, but needed more action on computer.

For afternoon-Excellent, Iliked it a lot!

For morning-Okay.

Okay.

Okay.

Okay.

Okay.

Okay.

Okay.

\section{Other Comments:}

This should be a fun week!

The graphs (bar-type with people) were ways to get us up and involved, but we seem to do them at all in-service and meetings lately.

The emphasis on this workshop is unclear. Is the emphasis on tomorrow's future kids, recycling, graphing, etc.? 
I really liked this, however, I have a hard time sitting for long periods.

I'm really looking forward to the rest of the week.

The unit type plan is a good idea to help coordinate activities, and the lesson plan is also. Is it necessary to do both? I would rather discuss the given plans in small groups-to enhance.

The information I received concerning the amount of time ( $120 \mathrm{~min} / 6-8$ weeks) to use NGS Kidsnet was rather vague until the workshop. Somehow I thought this could be more flexible. *It is also interesting to see styrofoam cups (environmental bad guys) at this workshop! But, I am not volunteering to wash dishes! 


\section{ACTIVITY: LESSON OVERVIEW - TOo Much Trash}

\section{August 2, 1994}

\section{Please write two or three sentences expressing your reaction to today's activity.}

Reviewing the lesson plans for the six weeks was very helpful. The step-by-step instruction on loading "Too Much Trash" was excellent!

Lesson Sessions: The units are great. I believe I could use them in my classroom with modifications and extended time. Sessions have been very beneficial.

I really enjoyed going through the unit today. I can hardly wait to get started.

Today's session was very helpful and beneficial in understanding the actual program until "Too Much Trash."

I was especially pleased with the way the presenters went through the unit and made suggestions.

Very informative. I feel better about using “Too Much Trash." I can't wait to get started on my 21st Century Bundle using "Too Much Trash."

There was a lot of information given today, and I am in information overload. Actually, the pace for the first sessions in the teacher's guide was slow, but good. It got a little too fast right before lunch, but we need to study it on our own anyway.

Today was a good day, had more hands-on experience.

Covering each unit was a great idea. Time spent in the computer lab was most valuable.

Today's activities were great. The teacher edition booklet was explained and how to use it. The computer hands-on was valuable. I am one that learns more from experience.

Going through the lessons was very boring. I am a visual learner, or need to have some activity.

It was very informative as to how to set up our lessons. A lot of good interaction.

Very informative day. Material covered was most helpful in improving my self confidence when teaching thisunit.

The exercise of going through the lesson plans was constructive and informative. I feel more prepared to eventually do the unit, and appreciated more the necessity of lead time to prepare my materials, organize materials, and collect newspaper and magazine articles. 
Very thorough. Well explained. Mosthelpful.

Today was a profitable day! I feel much more comfortable with the curriculum and the computer. The pacing today was much better.

This was a very interesting and informative day. I really appreciated the step-by-step procedure through the lesson plans.

I appreciated all the extra teaching tips. The morning lessons were very helpful in using whole language in this unit.

There were many useful ideas given (in addition) to the things already in our Teacher's Manual. I enjoyed the freedom of the afternoon to practice, ask questions and get individualized help.

Great! The unit "Too Much Trash" is beginning to make sense. It was helpful going through each lesson. If time had permitted, it would have been nice to share more teacher ideas, correlating units.

The activities today were well worth listening to! They were helpful in getting me familiar with the program. It was a lot better than expected regarding information given and teacher sharing information as we went through it.

\section{Three important things l've learned are:}

How to load "Too Much Trash," the approximate latitude/longitude of Chattanooga, the frightening statistics that 26 states will run out of landfill space by 1998 !

Classifying wastes, loading computer, using computer program.

Computer skills-installing "Too Much Trash" software, ideas for getting resource people into my class, how telecommunications work (hub-team idea).

How to install the program properly. How to go about preparing for each week. To stay updated on recycling information.

Recycle everything that is recyclable, because I don't always do that.

Start early on the unit. Have all materials handy. Stay on schedule.

How to load the program on the computer. Start two weeks early with my class. How to pull up more information on the computer map.

About how to use the lessons in my classroom.

Thanks for helping with hypercard. 
The deadline dates for telecomm are extremely important. Trash from the school can only be used. Compiling the data.

How to install the program in the computer, what activities and materials are in the lessons, when to telecommunicate.

The importance of a team following through.

It's in the book, take time to read and plan, be prepared.

I have a better overview of the assignment (unit). I need all the preparation time I can get. I will need to start working with my students quickly (beginning of school year) to prepare them for the unit.

To practice daily until my comfort zones are $\mathrm{OK}$.

More information on how to practically group students from different classes who will share project. Good overview of curriculum!

The importance of being early with data collection. The necessity in spending much time in preparation. The expectation of having a good, educational experience.

I learned how to use the manual to plan my lessons. Ilearned how to set up my global address, phone number, and $\mathrm{D}$ after the program is loaded.

How to install the program and get it up and running. How to keep track of the 120 minutes. Many ways to vary lessons - to adapt to your setting.

Styrofoam has numbers indicating degree of recyclability. Power Paragraph-how to feel comfortable with the unit.

Overview of NGS Kidsnet. What is necessary in planning of NGS Kidsnet. Best ways to teach the sessions.

\section{Two ideas or insights I would like to share with colleagues are:}

We as teachers can really impact others with our knowledge and example of saving our world from "Too Much Trash."

The importance of teaching our students the responsibility of reduce, reuse, recycle.

More cooperative activities.

Share this information with one or more of my colleagues. Especially the ones on my grade level. 
This is a great way for kids to learn cooperatively. Other teachers should get involved in this program.

Begin teaching key terms or activities early are very important.

How to install the program. What order you present the lessons.

You can do as little or as much as you have time and energy for.

Don't be afraid to ask. Just do the best you can; there's no right or wrong answers.

Great ideas shared today on integrating NGS Kidsnet with curriculum could be utilized by all sharing the program.

Pre-planning will pay off. This unit will cover many educational objectives.

It helps to walk through a program/lesson with someone. Open discussions lead to resource answers, help, etc.

Balloon with latitude/longitude. Using fruit with latitude/longitude.

\section{One action I will take tomorrow:}

Continue to encourage my neighbors to participate in our curbside recycling.

Recycle more, although my home area is not in the curbside recycling program.

I plan to really get down to business recycling. I must practice what I preach.

Grasp other ideas and activities from my fellow teachers to take back to class with me.

Work at the computer with the presenter.

I will be more diligent with the computer. I will take pleasure in listening to the plans of the other teachers.

I will travel to a landfill and learn more about how trash is stored.

Had more hands-on experiences with the computers.

Pay close attention to the hypercard process. It seemed detailed the first time around.

Actively participate in a lesson.

Learn to set up the computer. 
I will be here.

I want to find out as much as I can about other activities to correlate with this unit.

I will present my lesson plan. I will travel to a landfill.

Work on my action plan.

Generate more ideas to go along with "Too Much Trash."

Writing down my ideas as they come to me and writing other people's ideas to make a scrapbook for future use.

\section{How will I translate this back to my classroom?}

Initiate a recycling program in my classroom.

I plan to use the unit throughout the year and start a recycling program in my school.

I'm going to start a classroom recycling project, which hopefully will carry over into my whole school and then into the community.

I will translate this back to my class by successfully implementing this program in my classroom to where my students understand it, enjoy it and learn from it.

Being on task is very important in science; being diligent is even more important in science; try and try again until all data has been collected.

I will put my students in groups of 2 to 4 to work on this unit. If I have 28 kids and there are 9 to 12 research teams, is 2 or 3 students in a group too small for each group?

I am going to use as many hands-on activities as possible.

The information that I received today will be extremely helpful when I set my computers up for NGS Kidsnet. I really think that it will take a little time, but I am sure I will get the hang of it.

Show the students how to utilize this program.

I will be able to actually work the unit by following your guidelines.

Plan, but be flexible to the special needs of all.

Start working early in the year on social study skills and map skills. Teach some calculator skills. Explore early the processes a scientist uses and practice some areas. 
To cautiously practice weeks prior to the program, where we will be ready when time comes.

Many activities! Possible whole-language unit! Recycle/Invention fair sounds interesting!

I can easily say that early preparation will take place in my particular situation.

I will prepare my lessons and present them in an organized sequence.

Correctly installed program (I should be able to do this.) Ideas for lessons.

Providing more reference time on computers and telecommunicating.

The unit will be taught in a whole language approach and my ideas are endless.

\section{I would rate this activity:}

Excellent, Iliked it a lot!

Excellent, I liked it a lot!

Excellent, I liked it a lot!

Excellent, I liked it a lot!

Excellent, I liked it a lot!

Excellent, Iliked it a lot!

Excellent, I liked it a lot!

Okay.

Okay.

Excellent, I liked it a lot!

Okay.

Okay.

Excellent, I liked it a lot!

Excellent, I liked it a lot! 
Excellent, I liked it a lot!

Excellent, Iliked it a lot!

Excellent, I liked it a lot!

Excellent, I liked it a lot!

Excellent, I liked it a lot!

Excellent, I liked it a lot!

Excellent, I liked it a lot!

\section{Other Comments:}

An inspiring day! Thanks.

Thanks.

Thank you for the information today.

Disappointed in not participating in Internet.

Great day! 


\section{ACTIVITY: FIELD TRIP - Too Much Trash}

\section{August 3, 1994}

\section{Please write two or three sentences expressing your reaction to today's activity.}

I appreciated the time given to go over our action plan. Since we are driving each day, this is our only time together. Both afternoon trips were informative, especially the landfill (in an eyewitness kind of way)!

The Warner Park Recycling was very informative. I really enjoyed the lesson plans and ideas shared from the teachers. The landfill really made me think twice about helping to solve our waste problems and teach my students.

The man at the recycling center was super. It would be very difficult to not believe in recycling around him. The landfill was mind boggling!

I thoroughly enjoyed the morning and the chance to share and visit with the other teachers. The idea time was also interesting. The field trips were extremely good, surprisingly, and I really learned a bunch!

Aromatic experience! Sharing ideas was helpful. The field trips were very informative, and both resource people certainly knew their stuff.

Great resource person! The landfill trip was interesting.

Great sharing of ideas! Chance to see a landfill and recycling center.

Mr. _did an excellent job explaining the recycling process. He was most informative. I really enjoyed Mr. _'s presentation at the Chattanooga landfill site.

Today's activities were the most eye-opening experiences I've ever had. I will continue to recycle with more vigor.

Seeing and understanding about trash recycling. Sessions are very complete and enjoyable. Leader very knowledgeable.

The recycling center was extremely interesting. The dump was a little odorous but good ideas for us to see.

The visits were informative.

Very helpful hands-on, able to actually see and understand, very useful. 
Today's topics were very eye-opening. I have been to the recycling center before but never to the landfill. It will make a recycler of you!

\section{Three important things l've learned are:}

Our group has great ideas for lesson plan sharing! Today's trips have given me insight into some resources available. Try to stay with your group! — or things might happen.

Think before I throw anything away. Twenty years from now we will have a real problem if something isn't done. Not to be late.

Be a better consumer. After seeing the landfill, the importance of recycling paper.

Do not hesitate to use all sources of information. The importance of recycling. How wise and congenial the other teachers are.

Too much to write down! There is a new move to revamp plastic containers. Landfills contain too much paper which could be recycled. Chattanooga has some great recycling programs.

Good ideas from fellow teachers. Good information from Mr. __and the landfill trip.

Lessons/ideas to use in the classroom. What's at a landfill and recycling center. How you can utilize resources in the community.

I learned how other teachers are conducting lessons related to the workshop at their school.

Furthermore, I have a clear understanding of how important it is to recycle.

Recycling is "very, very" important; there are plastics that are not recyclable yet.

Landfills are filling up. Recycling is important. Reducing is important.

Reduce, recycle, reuse.

I will recycle and reuse before sending trash to the landfill. I will encourage everyone, including my students, to do the same.

To become more concerned about the environment.

How many items not recyclable, the correct recyclable procedure.

Chattanooga must find a better solution to trash disposal. Ineed to start composting. Landfills are not places I care to visit more than once. 
Two ideas or insights I would like to share with colleagues are:

Even though I also make globes I learned some tips to take back and share. An energetic attitude (like Mr. _ can turn student/teachers onto our trash dilemma and how we can help!

This is really an intelligent group of teachers. Ms. _ is fun. Mr. _ has done a great job.

The importance of reduce, reuse, recycle.

Do not hesitate to call and ask anyone for information concerning topics. Do not go to landfill following a rainy day.

I liked the recycled construction paper idea. Spreadsheet height/weight plot sounds good. Recycled treasure box.

How to do the ideas shared by others. What's at a landfill and what you would find at a recycling center.

We recycled newspaper at my school. This project turned out to be a great fundraiser. But most importantly, we did something about the waste problem in our community.

If you don't recycle, now is the time to start. Visit the landfill and you'll understand.

The importance of working as teachers to save our environment. We must start in our own classroom.

Get a bus for the field trips.

The visit to the recycle center, the visit to the landfill area.

Hands-on is best, procedures after.

Reduce, reuse, and recycle is not just a handy phrase-we need to do it. Very soon we will not have adequate areas to store trash.

\section{One action I will take tomorrow:}

Take time to check about printing files from the virtual school.

I will finish our action plans.

I'll look for more time to "pick the brains" of the other teachers for additional ideas and helpful hints. 
Spend more time searching through my "stuff" for ideas.

We will continue to pound out our action plan.

Working on the computer.

Iplan to write about our visit to TVA in my journal.

Put out my recyclables to be picked up.

Continue encouraging students to reduce, reuse, recycle.

Work with my partner to start an action plan to achieve the above.

Come early and work at the computer.

Teach students to become more aware of their surrounding.

To properly dispose of items for recycling.

I already recycle, but I will make an effort to recycle everything that it is possible to recycle.

\section{How will I translate this back to my classroom?}

Wealth of new lesson plans! On-site ( $\mathrm{CAB})$ experience with the trips-always helps. Factual knowledge of the process.

I will try to instill in their minds the concern that has grown within me this week about our waste problems.

I will use my influence as a teacher to convince my children to recycle, to be better consumers and to reduce even the use of paper.

Again, I'll over plan for this unit of study, as well as others. Continually, I notice how important preparation is.

Hopefully create an understanding of the importance of recycling and begin a recycling program.

I will consider field trips and will locate local resource people.

I'll be able to explain how recycling works in cities, and how a landfill is used in a community.

Iplan to discuss this information during grade level meetings. 
By using this unit with vigor.

I'm going to ask Mr. _ to speak to my class. Start a worm farm also.

To actually have displays, to actually walk children through.

I would like for my kids to visit both of these places because describing them is not powerful enough. Also, I'd like to start a school-wide recycling campaign and composting area.

\section{I would rate this activity:}

\section{Excellent, I liked it a lot!}

Excellent, I liked it a lot!

Excellent, I liked it a lot!

Excellent, I liked it a lot!

Excellent, I liked it a lot!

Excellent, I liked it a lot!

Excellent, I liked it a lot!

Excellent, I liked it a lot!

Excellent, I liked it a lot!

Excellent, I liked it a lot!

Excellent, I liked it a lot!

Excellent, I liked it a lot!

Excellent, I liked it a lot!

Excellent, I liked it a lot!

Excellent, I liked it a lot! 


\section{Other Comments:}

I enjoyed the field trips, but would have appreciated being taken in vans with our group to the sites. I realize that sometimes it's not possible, but would have been fun traveling and talking about each place. I must admit however, that I would not have had such an adventure had I been with the group. Ha! I'm glad we didn't let the rain stop our field trips. I was especially impressed with Mr. __ I'm glad I got the chance to hear him.

I thoroughly enjoyed the field trips. However, it is very difficult for out-of-town participants to find their way around a strange city with a time limit expectation. Please consider hiring a bus in the future.

The overall feeling of the workshop and the information continues to grow. Thanks!

I appreciate time to work on the "action plan!" Copying the teacher's manual has also been a great help!!

Thanks for giving us time to work on our action plan.

Best day of the year.

This was a good day - I love field trips.

Mr. _ of the recycling center was just great. The visit to the landfill was very interesting.

Mr. _ was very interesting.

Ilove both of the atlases as well as the other materials. Thanks!!! 


\section{ACTIVITY: Too Much Trash}

\section{August 4, 1994}

\section{Please write two or three sentences expressing your reaction to today's activity.}

The extra practice loading the program was very helpful. Also, the planning time was very good.

I feel great. I can bring this program up in my sleep. Thanks. Because of this I feel very comfortable.

Today was great! Working on the computers and going to school (searching for hypercard) was very helpful. We found it!!!

Today's activities were very helpful. I really like having the time to plan. The time on the computer was also very helpful.

Today was a practical day. Thank you. Working on the action plan made this very practical.

I really appreciated having time to plan and organize ideas on the best way to teach this unit. It takes a lot of time to familiarize yourself with a unit before teaching it. The time was well worth it today in planning.

I was very happy that we had time to work on the action plan. The time spent in the computer center, was well worth it.

Today was great for reinforcing the computer installation and for spending time on our action plan.

Because I knew how to load and work with the program, the day was a little slow. I enjoyed time to plan.

I was able to telecommunicate. I had a chance to develop a plan for my school utilizing the NGS Kidsnet units.

I will be able to walk my faculty through the entire program because of extra practice on computer and one-on-one with a buddy.

I enjoyed the time with the computer practicing and learning a few more things. I did have a bit of extra time, however, since I felt comfortable with the computer program.

Helpful in viewing Hello and Acid Rain, plus the opportunity to preview other software. Planning time was helpful, but it would be beneficial if participants knew our scheduled time before training.

Learned a lot about the computer-Hope I can do it. Worked on School's Action Plan to begin getting involved. Where to get information to use with the unit. 
Thanks for providing extra time on the computer. You have done an excellent job attending to individual needs. I am impressed by all of the helpful information written on the board daily.

This was a great benefit to me as I had the opportunity to plan without other school pressure. I valued the computer time to feel more comfortable with the programs.

I really appreciate the free time to interact with the other teachers, not only those from my area. Seeing the video was very helpful. Could we have viewed it earlier in the week?

Thanks! I feel much more confident about using NGS Kidsnet. I know how to load and use my program.

I feel much more comfortable installing NGS Kidsnet today. Providing ample time to use the computers was the key, as well as having Mr. _ there to answer any questions that I might have.

A lot of time to plan. Thanks.

It was practical and worthwhile. Had a chance to understand the computer more.

\section{Three important things l've learned are:}

I reviewed loading the program. I was more comfortable using the program.

To be more confident using "Too Much Trash," computers are user friendly.

We already have hypercard!!! How to save a letter and get it back. The various map data in "Too Much Trash."

I learned how to save documents. I really learned how to install the software. I learned how to prepare the action plan.

Worked on action plan.

How to integrate social studies, math and science better. How to make learning more interesting for kids. I'm more relaxed with telecommunications.

How to load a program onto a computer. How to save a document and retrieve it. Be willing to take chances.

I learned how to connect a modem. I learned that all NGS Kidsnet programs operate in the same manner.

How to telecommunicate. How I can use this program in my school. How to save and retrieve a letter. 
How to network. How to store data. How to use telecommunications.

How to find and change memory on hypercard. How to install program. Actually telecommunicate.

Two available videos.

Installing the program. Using the program. Collecting materials for using in my class (how to get info).

I have learned how to use the desktop for "Hello." The videotape was most helpful in regards to learning how to use the IBM computer.

Information about other software.

Installing NGS Kidsnet. "Knowing and Remembering" 1400K memory. "Saving" documents.

How to use computer, how to use the program.

Two ideas or insights I would like to share with colleagues are:

This workshop is great.

Take this workshop!

It is very helpful to have another person at your site for support.

Take time to become a part of NGS Kidsnet.

Technology is the way of the future.

How to telecommunicate, and how we can use this program in our school.

Be patient, keep trying everything Mr. _ said was true because I tried it for myself. I can telecommunicate.

Share installation. Share some tips I learned with MAC computers.

Use the materials inside the NGS Kidsnet Science Kit to order additional software.

\section{One action I will take tomorrow:}

I'll learn how trash is sorted.

Feel good because I am confident to start the year with something very exciting. 
Call and get my school's latitude/longitude.

Recheck our plan to make sure.

Traveling to UTC.

Ask questions about things that are not.

Visit to TVA.

Go to TVA Energy Center.

Be more excited about the knowledge I've learned. Be certain every student within my class know thoroughly how.

Try to be ready to ask any questions as it's the last day.

Find more resources for unit.

Already began working on total school population; getting involved with the $3 \mathrm{R}$ 's.

Photograph or videotape my visit to TVA.

One action I will be taking continually is to search and file for information related to "Reduce, Reuse, and Recycling" unit.

\section{How will I translate this back to my classroom?}

The program is getting easier to use. The kids should be able to handle it.

Through excitement and enthusiasm.

I will use "Hello!" with my students (I can't wait)! We will implement our "Action Plan" for "Too Much Trash" with the beginning of school; including our staff, faculty, parents, students, school "adopters," and community.

The action plan should help the "Too Much Trash" go much more smoothly.

I will prepare for the unit in advance and be ready to begin the unit on time.

Show them how to telecommunicate and to save and retrieve a letter.

At the moment practice and pre-practice for real run. 
Hopefully be able to remember these things long enough to teach others.

Help in planning unit.

Not only my classroom — but school, community, PTA to get involved with program (3R's).

I intend to use the photograph and videotape as I discuss the workshop.

I will have a well-thought-out unit and not be pressured.

I would rate this activity:

Excellent, I liked it a lot!

Excellent, I liked it a lot!

Excellent, I liked it a lot!

Excellent, Iliked it a lot!

Excellent, I liked it a lot!

Excellent, I liked it a lot!

Excellent, I liked it a lot!

Excellent, I liked it a lot!

Excellent, I liked it a lot!

Excellent, I liked it a lot!

Excellent, I liked it a lot!

Okay.

In between excellent, I liked it a lot! and okay.

Excellent, I liked it a lot!

Excellent, I liked it a lot!

Excellent, I liked it a lot! 
Excellent, I liked it a lot!

Excellent, I liked it a lot!

Excellent, Iliked it a lot!

Okay.

Okay.

\section{Other Comments:}

This has been great! I appreciate everyone's hard work!!!

The computer time was well worth it especially for uncomfortable computer users.

The part I valued most was going over each individual session in detail. I also valued ideas being shared between colleagues. New ideas bring excitement.

This workshop has been great! I really feel comfortable taking this back to my classroom and using it.

ThankMr. _ for a wonderful wealth of knowledge. Prayerfully, I can and will enlighten all of my students. Ms. _ I I thank you for directing this training.

Workshop needs to be held at a site where we can have access to Internet printers, DOS and MAC computers. How about other software that may correlate with Unit Plan.

Thanks for providing time to work on our Action Plan.

It would be helpful to have more materials available for previewing.

I can't "thank you" enough for your help and outstanding supply of materials.

I had the opportunity to work for some time on the computer which will help when I get home. 


\section{ACTIVITY: TVA VISIT - Too Much Trash}

August 5, 1994

\section{Please write two or three sentences expressing your reaction to today's activity.}

It was very interesting to see how TVA handles a recycling program. I can't wait to try this at my school. The estimation and graphing exercises were useful.

Very informative. Glad to know that TVA is in the recycling business. "An ounce of prevention is worth a pound of cure."

TVA was a great experience. Ienjoyed hearing about their experience in recycling, loved all the information and resources given to us.

I was impressed by TVA's recycling efforts. It will encourage children if they are unsure of parents' efforts to recycle.

The presenters did an excellent job describing the recycling program at TVA.

Awareness of seriousness of trash as a serious environmental problems. Good ideas about recycling. Knowledge about outside resources.

The field trip to TVA was very helpful and informative.

Enjoyed the visit to TVA-was informative and very interesting. The speakers were knowledgeable.

\section{Three important things l've learned are:}

We need to find new solutions for disposing of trash. The ReBox is a great idea and easy to use. TVA has its own recycling center.

Big companies can recycle successfully. An ounce of prevention is worth a pound of cure.

Students could be trained to handle recycling at school just as Orange Grove students were.

Great resources are found all around you! Error Bar-giving the range estimation.

All of the information presented at TVA was most helpful. I thought the lesson on how to translate English into graphs was very important.

To reduce, reuse, recycle. To help others to learn to reduce, reuse, recycle. To get the message around for the need to reduce, reuse, recycle.

That TVA was doing a coop with other businesses. The range aspect of estimation.

To become more aware of the environment. How to use the computer. How to load the computer. 
Two ideas or insights I would like to share with colleagues are:

We definitely need to start a school-wide recycling program. It will not be very difficult to implement.

If you have a chance to attend the NGS Kidsnet, please do. It's really worthwhile.

Recycling is easier than it seems. Recycling could spread throughout the community.

Resources are everywhere!

I'm going to tell faculty/staff members at school about TVA's efforts to reduce waste.

They must take care of the environment. Learn to recycle at home and at school.

\section{One action I will take tomorrow:}

I will continue to recycle, but I'll try to do an even better job at it.

Encourage as many people as I can to participate in the curbside recycling.

Talk to my students' parents as I enroll and meet my class—-tell them about our school-wide project.

Sleep late!

Summarize notes taken during this wonderful week of learning.

Begin recycling "more" immediately.

Sleep late.

\section{How will I translate this back to my classroom?}

I'd like for the 5th grade to be the school leaders in setting up a school-wide recycling program.

We will start the year talking about recycling so that, by the time we get to the "Too Much Trash" computer programming, we will be well on our way to a good recycling center.

I plan to set up bins and "reboxes" in my class.

I'll have the students find resources from the community on various projects-also have them contact different businesses to see what they are doing about recycling!

I will share the content of the workshop with teachers during grade level meetings. 
Begin the "Too Much Trash" unit as soon as school begins.

I will use TVA as a resource and also spend a lot of preparatory time in estimation.

Will teach students to become more aware of their surroundings.

I would rate this activity:

Excellent, I liked it a lot!

Excellent, Iliked it a lot!

Excellent, Iliked it a lot!

Excellent, I liked it a lot!

Excellent, I liked it a lot!

Excellent, I liked it a lot!

Excellent, I liked it a lot!

Excellent, Iliked it a lot!

\section{Other Comments:}

Terrific!

This is the best, most practical workshop that I have ever attended.

Outstanding! Thanks for a wonderful workshop and superb materials.

Very good. Well organized and prepared workshop. Everything flowed smoothly. The presenter Mr. _ was very knowledgeable about the subject.

The week has been very productive. The team leader was excellent. I enjoyed him very much. 